\title{
Landscape Structure, Landscape Metrics and Biodiversity
}

\author{
Ulrich Walz \\ Leibniz Institute of Ecological Urban and Regional Development (IOER) \\ Weberplatz 1, D-01217 Dresden, Germany \\ email: u.walz@ioer.de \\ Accepted on 6 October 2011 \\ Published on 4 November 2011
}

\begin{abstract}
This paper deals with the question of the role landscape metrics can play in the investigation, evaluation and monitoring of landscape structure, and which linkages between landscape structure and biodiversity are known. In the first part, the scientific state of the art is presented; in the second part, the meaning of landscape metrics for nature protection, landscape management and biodiversity monitoring is discussed. A number of studies indicate that such metrics on an aggregated, overall landscape level are quite appropriate to describe the state of biodiversity. On the other hand, gaps in the knowledge become apparent, and the results of such studies are strongly dependent on the scale of investigation and the underlying database. Nevertheless, the landscape structure approach seems to be expedient for management and planning at the landscape level.
\end{abstract}

Keywords: landscape mosaic, heterogeneity, landscape functions, biological diversity, landscape pattern, spatial planning, landscape management, nature conservation

This review is licensed under a Creative Commons Attribution-Non-Commercial-NoDerivs 3.0 Germany License. http://creativecommons.org/licenses/by-nc-nd/3.0/de/ 


\section{Imprint / Terms of Use}

Living Reviews in Landscape Research is a peer reviewed open access journal published by the Leibniz Centre for Agricultural Landscape Research (ZALF), Eberswalder Straße 84, 15374 Müncheberg, Germany. ISSN 1863-7329.

This review is licensed under a Creative Commons Attribution-Non-Commercial-NoDerivs 3.0 Germany License: http://creativecommons.org/licenses/by-nc-nd/3.0/de/

Because a Living Reviews article can evolve over time, we recommend to cite the article as follows:

\section{Ulrich Walz,}

"Landscape Structure, Landscape Metrics and Biodiversity", Living Rev. Landscape Res., 5, (2011), 3. [Online Article]: cited [<date >], http://www.livingreviews.org/lrlr-2011-3

The date given as $<$ date $>$ then uniquely identifies the version of the article you are referring to.

\section{Article Revisions}

Living Reviews supports two ways of keeping its articles up-to-date:

Fast-track revision A fast-track revision provides the author with the opportunity to add short notices of current research results, trends and developments, or important publications to the article. A fast-track revision is refereed by the responsible subject editor. If an article has undergone a fast-track revision, a summary of changes will be listed here.

Major update A major update will include substantial changes and additions and is subject to full external refereeing. It is published with a new publication number.

For detailed documentation of an article's evolution, please refer to the history document of the article's online version at http: //www.livingreviews.org/lrlr-2011-3. 


\section{Contents}

1 Introduction $\quad 5$

2 Definitions $\quad 5$

3 Methods of landscape structure analysis $r$

4 Relations between landscape structure and biodiversity - scientific state of the $\begin{array}{ll}\text { art } & 7\end{array}$

4.1 Landscape structure and diversity of species . . . . . . . . . . . . . . . . . . . 8

4.2 Landscape metrics for monitoring biodiversity . . . . . . . . . . . . . . . . . . . . . 11

5 Conservation and management issues - landscape metrics for spatial planning and nature protection

6 Conclusions

7 Acknowledgements

References

\section{List of Tables}

1 Selected indicators reliable to biodiversity and land use change in Germany and their use in the different indicator systems . . . . . . . . . . . . . . . .

2 Indicators of quality of landscape structure in the framework of spatial ecological

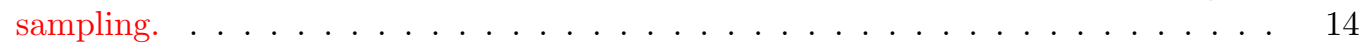

3 Important landscape metrics in the field of biodiversity . . . . . . . . . . . . 



\section{Introduction}

The structure of a landscape, i.e., its composition and arrangement, and the resulting spatial relationships between its individual elements, can be described and quantified by means of landscape metrics. This instrument has been used for more than 20 years in Europe and North America in a variety of studies in the scientific and experimental area. They are now finding their way into such practical applications as assessment procedures for planning (Botequilha Leitão and Ahern, 2002) and monitoring (Wrbka, 2003; Heinz Center, 2008). The present review paper elucidates the role that landscape metrics can play, particularly in the collection of the relevant information, and in the evaluation and monitoring of biodiversity. The focus of the paper is laid on landscape metrics as a means to describe landscape structure and as indicators of biodiversity and the question of which aspects of biodiversity can be met by landscape metrics. Known fields of application in monitoring and landscape management are presented; the impediments encountered, too, are identified.

\section{Definitions}

First of all, some explanations of the key words of this article should be given. Landscape structure means the pattern of a landscape, which is determined by its type of use, but also by its structure, i.e. the size, shape, arrangement and distribution of individual landscape elements. For the delineation of these landscape elements, or so-called "patches", often land use or land cover units are used. In this context, "land cover' refers to the physical surface characteristics of land (for example, the vegetation found there or the presence of built structures), while 'land use' describes the economic and social functions of that land." (Haines-Young, 2009, 179). Of course, other spatial elements can also be used, e.g. soil units, habitats or vegetation units from phytosociology.

The heterogeneity of landscapes - as a parameter of landscape structure - is connoted as the "quality or state of consisting of dissimilar elements, as with mixed habitats or cover types occurring on a landscape". It is the "opposite of homogeneity, in which elements are the same" (Turner et al., 2003, 3).

As indices of landscape structure, landscape metrics can be used to describe the composition and spatial arrangement of a landscape. They can be applied at different levels to describe single landscape elements by such features as size, shape, number or for whole landscapes by describing the arrangement of landscape elements and the diversity of landscape. The reason for using these metrics in spatial analysis may be to record the structure of a landscape quantitatively on the basis of area, shape, edge lines, diversity and topology-descriptive mathematical ratios; to document for purposes of monitoring; or to make the relevant information available as input parameters for landscape ecological simulation models.

Overviews of the current discussions and the application of landscape metrics are given on the use of landscape metrics for landscape analysis with Geographic Information Systems (GIS) by Lang and Blaschke (2007), the application of landscape metrics in nature protection and landscape research by Blaschke (2000) and Uuemaa et al. (2009), on existing landscape metrics and software by McGarigal et al. (2002) and Walz (2006), and on landscape pattern and landscape indicators by Bolliger et al. (2007).

For a definition of biodiversity (or biological diversity), the Convention on Biological Diversity (1992) is often cited (United Nations, 1993): "For the purposes of this Convention ... 'Biological diversity' means the variability among living organisms from all sources including, inter alia, terrestrial, marine and other aquatic ecosystems and the ecological complexes of which they are part: this includes diversity within species, between species and of ecosystems." Biodiversity thus comprises the fields of genetic diversity, species diversity (number of species in certain units of 
space) and diversity of habitats and ecosystems at the landscape level (see Blab et al., 1995, 11, Figure 1). Thereby, each level is dependent on each other. The dynamics of natural processes, such as the changing distribution patterns of species and habitats in space and over time, are also part of biological diversity (Blab et al., 1995, 11). At each level of biodiversity, three fundamental characteristics of biodiversity can be considered: composition, structure and function (Noss, 1990; Waldhardt and Otte, 2000). Composition describes the individuality and variety of elements, such as land use units or species within a region. Structure, by contrast, refers to the arrangement or the construction of units, the distribution of elements and their relationship to one another. Function, finally, comprises all processes, such as demographic trends, cycles of material or disturbances (Lipp, 2009, 37). Especially at the landscape level, composition and structure can be described by landscape metrics.

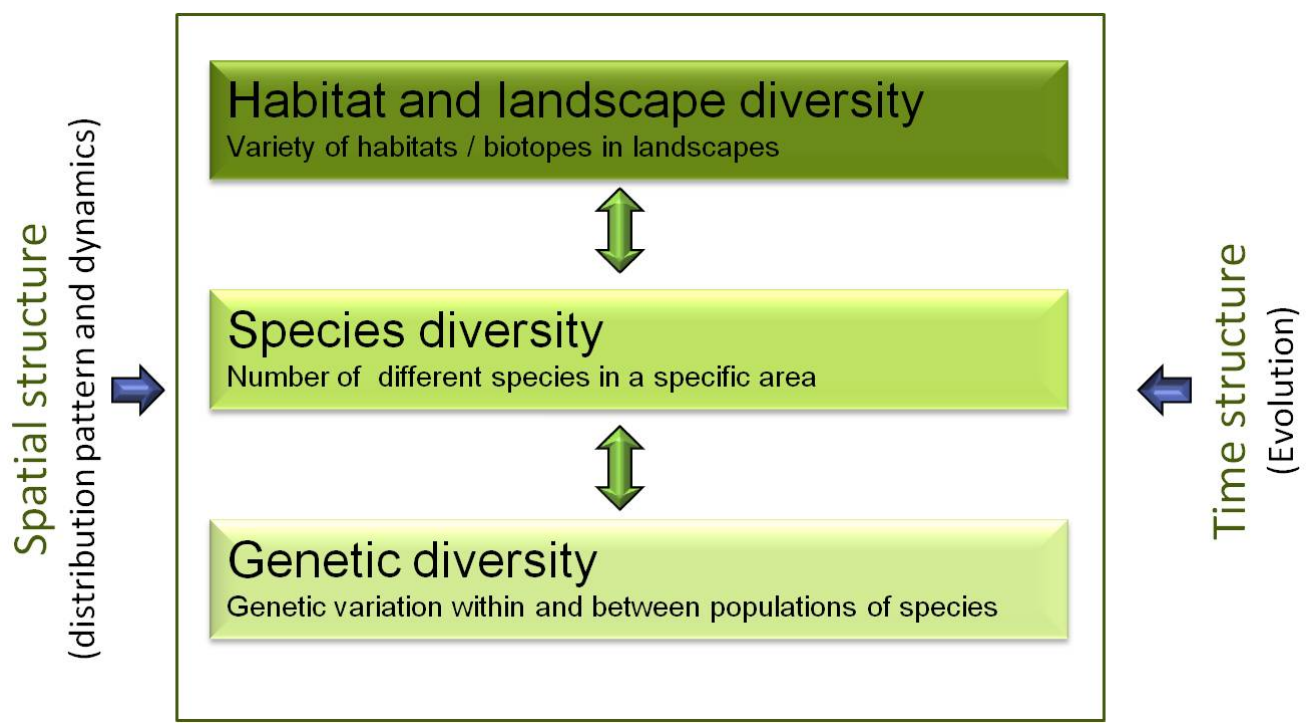

Figure 1: Levels of biological diversity. Adapted from Blab et al. (1995).

Biodiversity depends on geo-diversity, i.e., the variety of natural conditions, such as relief, soil characteristics and local climate, but in cultural landscapes also on the land use. Geo-diversity, biodiversity and land use diversity as a whole can be called "landscape or eco-diversity" (Jedicke, 2001, 60). Today, the anthropogenic influence in most regions is very high. A clear distinction between natural and cultural landscapes is virtually impossible. For this reason, it is important not only to consider the natural areas or landscape elements, but also the influence of man, for example, by investigating land use and land use structure.

\section{Methods of landscape structure analysis}

Use of Geographic Information Systems (GIS) is required to analyse landscape structure using landscape metrics. GIS is necessary due to the need to evaluate a large amount of spatial information (such as land use information, habitat types, soil types) and in order to overlay and intersect this information with other information, enabling the parameters of landscape structure to be calculated. In addition, spatial reference units (e.g., natural or administrative units or regular fishnets) are required. Only by overlaying georeferenced spatial data and computing partial complex mathematical formulas can landscape structures in large areas be analysed.

Living Reviews in Landscape Research

http: //www. livingreviews.org/lrlr-2011-3 
A number of specialised software programmes are now available for calculating landscape metrics. One of the first programmes to appear on the market was FRAGSTATS (McGarigal and Marks, 1995), followed by PatchAnalyst (Rempel, 2008) and V-LATE (Tiede).

As the data basis, land use data from official land use surveys or remote sensing data, especially for large areas (e.g., Groom et al., 2006), are often used. One of the main problems in analysing landscape structure is that the landscape elements need to be delineated and defined, which may be extremely difficult and arbitrary in some types of landscape. In reality, it is often not easy to delineate a landscape element because sometimes no clear line distinguishes a landscape element from a neighbouring element. Some authors have proposed considering the landscape as gradients (McGarigal and Cushman, 2005; Bolliger et al., 2007), e.g., the transition zones between patches. Indeed, in most studies, the delineation of landscape elements is a simplification of reality, which depends on data source, scale and, ultimately, the interpreter.

The thematic and geometric resolution influences the results of analyses using landscape metrics (Baldwin et al., 2004; Castilla et al., 2009; Mas et al., 2010). It is crucial that the scale of investigation (Wiens, 1989, 386) and the spatial resolution of the data correspond to one another (Corry, 2005, 606). Fine-scale or multi-scale methods may be more informative than those based on only one, or very coarse, scales. For example, in a study by Lawler and Edwards (2002, 242), a coarse resolution of $30 \mathrm{~m}$ and higher seemed to be insufficient for statements about bird habitats. The need for multi-scale studies is also illustrated by the fact that studies of habitats often provide different results at different scales for the same species (Corry, 2005, 606). The decision which information on land use classes should be included in the landscape structure analysis (thematic resolution) is dependent on the aim of the investigation. The information depth of the data, such as land use/land cover, should meet the necessary habitat use or habitat types for the investigated species. Sometimes the similarity of types of landscape element is also important for biodiversity at the landscape scale.

Another simplification of reality is that, in most cases of landscape structure analysis, the underlying relief is not considered. In GIS analyses and calculations of landscape metrics, only planimetric areas and distances are calculated. With extreme reliefs in particular, this can lead to differing results from calculations with "real" areas and distances (Hoechstetter et al., 2008; Jenness, 2004; Blaschke et al., 2004; Dorner et al., 2002).

These limitations should be borne in mind and viewed with caution when comparing results from different areas and studies. Care must be taken that the data sources, methods and scales are indeed comparable. The selection of landscape metrics as indicators must also ensure they reflect the real demands of the species under investigation (Dormann et al., 2004, 70-71).

\section{Relations between landscape structure and biodiversity - scientific state of the art}

Biological diversity in all its dimensions and facets is always tied to habitats, which need a concrete areal section of the earth's surface for their existence. Biological diversity is therefore always defined for a certain reference area, and landscape structure is a key element for the understanding of species diversity. Spatial heterogeneity, as an expression of landscape structure, indicates the variability of the system's properties in spatial terms (Kolasa and Rollo, 1991; Li and Reynolds, 1995). Therefore it is regarded as essential for the explanation of the occurrence and distribution of species from the local to the global level (Ernoult et al., 2003, 240). Against this background, an increasing number of studies analyse the relationship between landscape structure and biodiversity. The goal is to find variables for modelling the spatio-temporal distribution patterns of species and communities (see Bissonette, 1997; Dufour et al., 2006; Schindler et al., 2008, 503). 


\subsection{Landscape structure and diversity of species}

It is often mentioned in very general terms that the spatial pattern of the landscape influences many ecologically relevant processes, e.g., the distribution of materials and nutrients or the persistence and movement of organisms (Turner, 1989, 189). But what connections between the type and structure of land cover and biodiversity can be found in the literature? An initial overview is given in Uuemaa et al. (2009, 8-11). Numerous studies have shown such relationships to be determinants of species diversity (Ricotta et al., 2003, 373). In the following sections, examples from the literature of linkages and variables are given. These are considered important to the relationship between landscape structure and species diversity / patterns of species distribution.

\section{Plants}

Important preconditions for high biological diversity are the abiotic site conditions and the geomorphology. Habitats with spatially heterogeneous abiotic conditions provide a greater variety of potentially suitable niches for plant species as habitats with homogenous characteristics. Variations in physical structure (e.g., slope direction, soil structure) have proven to be an appropriate factor for the prediction of the richness, diversity and dominance of plant species (e.g., Hobbs, 1988; Lapin and Barnes, 1995; Burnett et al., 1998; Nichols et al., 1998; Honnay et al., 2003, 241). For example, in studies by Burnett et al. in deciduous forests, the sites with high geomorphological heterogeneity were those with the highest plant diversity (Burnett et al., 1998, 367-368). There, the variances in plant abundance and diversity were explained best by slope direction and the water balance. Because of the strong correlation of the abiotic variables and biological diversity, these factors can be used to predict relative levels of biological diversity (Burnett et al., 1998, 368).

By contrast, in a landscape like the Central European cultural landscape, the composition and diversity of plant species depend on the structure of use affected by people. With respect to area size, Bastian and Haase $(1992,27)$ found that the relationship between the number of plant species and area size can be described with statistical assurance by means of a logarithmic function. With increasing surface area of shrubs, the proportion of typical forest species in the total number of species also increased (Bastian and Haase, 1992, 27).

The shape of habitats can affect the number of species, too. For a greater number of environmental transitions between irregularly shaped habitats, areas can generally include more plant species (Honnay et al., 1999, 2003, 241-242). Therefore, shape complexity can be used to analyse land cover data as an index for species richness (O'Neill et al., 1988; Miller et al., 1997), which improves the accuracy of the prediction of plant richness. Geometric landscape complexity proved to be a sensitive indicator of plant richness, especially in agricultural landscapes (Moser et al., 2002, 666).

In fragmented landscapes, the distance to viable habitats (isolation) also determines the composition and abundance of plant species (Grashof-Bokdam, 1997; Butaye et al., 2001). Less isolated habitats are generally more species-rich because they can be easily settled. The constant influx of new individuals prevents local extinction due to demographic and environmental coincidences (Shaffer, 1981; Honnay et al., 2003, 241).

An increase in the degree of urbanisation (increase in area proportions and sizes of settlements and green spaces, traffic density and shrubs structures) correlates in particular with an increase in the number of species of neophytes, but also with an increase in archaeophytes and indigenous species. The same is true for the increase in border and seam structures in the landscape, which create possibilities for settlement (Deutschewitz, 2001, 88). Some species are closely related to elements of landscape structure, such as edges, roads and certain land use types (Brosofske et al., 1999, 212).

Also, in agricultural landscapes, ecotones, which are linear landscape structures between different habitat types, have significant benefits, mainly because they provide habitats after the

Living Reviews in Landscape Research

http://www. livingreviews.org/lrlr-2011-3 
harvest and for hibernation. Ecotones with high structural heterogeneity, such as forest fringes and hedgerows, provide an improvement, too, for regional biodiversity, as they do for the richness and diversity of beneficial organisms (Duelli, 1997, 82).

Natural disturbances along streams, the structure and variety of land use in floodplains and natural distribution mechanisms are linked to high biodiversity of indigenous species, but also promote the establishment and spread of neophytes and archaeophytes (Deutschewitz, 2001, 88).

These relationships can be made comprehensible by means of landscape metrics. Honnay et al. $(2003,248)$ were able to show that regional plant variety can be predicted satisfyingly on the basis of relatively simple landscape metrics.

\section{Animals}

The linkages between wildlife and landscape structure are similar. However, there are differences, in particular due to the mobility of animals. Thus, species with good ability to spread depend mainly on landscape composition, i.e., the proportion of their preferred habitat type. Landscape structure is less important for these mobile species (Visser and Wiegand, 2004, 59). By contrast, for species with poor dispersal ability, both landscape composition and landscape structure have an arbitrative influence on the frequency of the species. The effect of landscape structure can be reduced to a scale-dependent metric: the average frequency of suitable habitat in a species-specific distance (Visser and Wiegand, 2004, 59). Edge effects and distances between patches can influence the permeability of a landscape. For example, results by Romero (2007) show the dependence of the migration behaviour of beetles on landscape structure.

The process of fragmentation of landscapes, in the sense of the piece-meal conversion of a formerly contiguous habitat, usually primarily affects animals with relatively large territories e.g., birds or large mammals. On the other hand, animals with limited mobility are separated into isolated populations more rapidly by such elements as roads or urban structures (Swenson and Franklin, 2000, 714). However, in science there is no consistent understanding of the term landscape fragmentation (Jaeger, 2002). Today, the term is increasingly used internationally as synonymous for all anthropogenic invasions of landscapes and habitats. By contrast, the German concept of Zerschneidung (lit.: cutting apart), which is usually translated as "fragmentation", emphasises the network of linear and areal artificial land use elements, such as roads and settlements. This is understood to be an active process which "cuts" spatial connections and interrupts functions. Such land use changes caused by the demand for land for settlement and landscape fragmentation are currently seen as a major cause of the continuing loss of biological diversity worldwide (SRU - Sachverständigenrat für Umweltfragen, 2005, 52). Several landscape metrics are now used for the measurement of landscape fragmentation through infrastructure (Walz and Schauer, 2009). The most widespread fragmentation metrics are the number and size of unfragmented areas with low traffic (UVR) (Lassen, 1979; Bundesamt für Naturschutz, 2008) and of effective mesh size ( $\left.\mathrm{m}_{\mathrm{eff}}\right)$ (Jaeger, 2000).

In many cases, the direct loss of habitats or ecosystems is probably the superior predictor (Strand et al., 2007, 147-148), even ahead of landscape fragmentation, because habitat size and diversity play an important part. Certain species prefer more diverse territories (greater number of patches, smaller size, more edges), as demonstrated by Fernández et al. (2007, 437), e.g., for the Iberian lynx or the ocelot (Jackson et al., 2005, 733). For bats, relationships between patch size and patch density have been shown in forest areas. Thus, the species richness of bats was highest in partially deforested landscapes (Gorresen and Willig, 2004, 688). Bees also need specific habitat combinations that can be described using landscape metrics. This makes it possible to predict the potential diversity of bees (Bailey et al., 2007, 470).

The shape of patches may play a role, too. It was shown for the ruffed grouse (Bonasa umbellus) that regularly shaped patches are preferred (Fearer and Stauffer, 2003, 109). Overall, it 
is clear that animals can react differently to habitat diversity. Different scales have to be taken into account. The identification of such scales remains a key objective in landscape ecology (Turner, 2005, 329).

Ecotones or edges, as transition zones, are often particularly rich in species. In studies of edge biotopes in the agricultural landscape of Saxony-Anhalt, species numbers were almost twice as high as those within the fields. The species composition and dominance of edge biotopes were very different from those in the fields. Introducing edge habitats to forests can also affect the fauna. In such cases, species richness may temporarily increase due to migration of specific edge species, but only at the expense of species of the forest interior. Therefore, birds can be useful as an ecological indicator (Noss, 1983, 702).

The environment of the habitats, i.e., the context and surrounding landscape matrix, plays an important part. For the management of grassland birds, for example, it is important to include quantity and context of the embedded habitats, i.e., the surrounding matrix as well as food resources (Hamer et al., 2006, 581).

The degree of disturbance by landscape change and other factors of human influences in the surroundings have a significant impact on species richness. Thus, for the correlation of birds communities with road density and forest area, the distance to the nearest built-up area, the density of human settlement, and the degree of imperviousness were found to be significant factors (Sundell-Turner and Rodewald, 2008, 223).

Geomorphological diversity also emerged as a significant impact for the fauna. Due to the mobility of animals, however, it appears to be less limiting than it is to plants. However, many animal species depend on certain plant species (Burnett et al., 1998, 368).

\section{Habitat modelling}

Landscape metrics are also used for habitat modelling of individual species or species groups, e.g., by Dormann et al. (2004); Fauth et al. (2000); Fernández et al. (2007); or Grillmayer (2000). For example, Steiner and Köhler (2002) were able to show the existence of a clear dependence of the species diversity on landscape structure in model experiments. With a decreasing degree of landscape heterogeneity in the model, both local and regional species diversity also decreased. The importance of considering space, habitat structure and landscape patterns is illustrated by Dormann et al. (2004, 70-71).

\section{Results on linkages between landscape structure and species}

In the literature analysed, the following properties of landscape patterns that have a positive effect on biodiversity were mentioned:

- a high proportion of semi-natural biotope types;

- large areas;

- high biotope diversity;

- high structural diversity;

- high connectivity;

- high geomorphological diversity.

However, some of these properties are mutually exclusive (for example, high structural diversity and large surface area of individual patches) (Zebisch, 2004, 27). In addition, properties that are beneficial for a single species can be definitely disadvantageous for another. Depending on the

Living Reviews in Landscape Research

http://www. livingreviews.org/lrlr-2011-3 
specific characteristics of the organisms, and depending on the spatial scale, the effect of landscape structure on the viability of the organisms can vary greatly (Visser and Wiegand, 2004, 62). No clear assignment to a quality (e.g., "high structural diversity is desirable") is possible (Zebisch, 2004, 27).

Furthermore, land use in and of itself may be not sufficient to predict species richness and distribution. In studies by Cardillo et al. (1999, 432-433), it explained less than half of the species richness and occurrence. Therefore, a set of variables should be used, which includes the land use in conjunction with such other landscape characteristics as habitat structure, composition of vegetation and soil characteristics. However, particularly in cultural landscapes, the influence of land use on patterns of species distribution could be greater than the influence of the original and natural landscape parameters. For investigations at the regional level, land use can be crucial for species composition and richness (Deutschewitz, 2001, 78).

All in all, Duelli $(1997,88)$ and many other authors (e.g., Bailey et al., 2007; Ortega et al., 2004) hold that the evaluation of patterns of the landscape mosaic can serve as a substitute for the recording of regional biological diversity, as a form of knowledge-based assessment. In general, broad environmental diversity leads to high species diversity (Ricotta et al., 2003, 373). Size, surface area and spatial relationships between patches thereby play an important role (Dale et al., 2000, 639). In accordance with the "mosaic" concept, regional biodiversity depends mainly on such structural parameters as habitat diversity or landscape heterogeneity, and the dynamics of metacommunities (Duelli, 1997, 81). As relevant measures, he mentions the diversity and heterogeneity of habitats, and the portions of natural and semi-natural habitats (see Table 2). Thereby it is assumed that such areas rather have a great diversity of habitats due to their size and therefore also greater biological diversity (Dramstad et al., 1996; Botequilha Leitão et al., 2006, 11). Also Honnay et al. $(2003,248)$ come to the conclusion that landscape metrics appear to be suitable to predict biotic processes. Therefore, according to Duelli (1997), the assessment of biodiversity at a higher, integrated level can be based on landscape parameters.

\subsection{Landscape metrics for monitoring biodiversity}

Since the complexity of biological diversity is difficult to describe, most ecologists have taken the practical way to research and to identify the biological diversity at the species level (Feest et al., 2010, 1078). Therefore, the selection of structural indicators was undertaken specific to the habitat type or tested species studied. Local data on species diversity can provide information as a proxy for regional biodiversity. An investigation of flora and fauna is, however, typically not comprehensive, but rather generally covers only a small proportion of all species. The clear determination of the diversity of various taxonomic groups requires very high efforts, knowledge and money. Hence a good substitute is needed. By combination of indicator species and groups with spatial environmental data (Heino, 2010, 112) and landscape structure, the power and deputy information can be increased and expanded geographically (Faith et al., 2003, 317).

Which parameters are suitable for the characterisation and description of landscape diversity, and can therefore be used as an indicator for biodiversity? In principle, a few indicators are sufficient to ascertain landscape patterns (Riitters et al., 1995; Cain et al., 1997; Lausch and Herzog, 2002, 13). However, biodiversity cannot be described only by a simple number, as there are various qualities of spatial patterns (Tischendorf, 2001; McAlpine and Eyre, 2002; Neel et al., 2004). A selection of indices representing various aspects of biodiversity is much more informative and capable of interpretation (Feest et al., 2010, 1080). However, the use of many highly correlated indices provides no new information, and leads to problems in interpreting the results (Jones et al., 2001; Li and Wu, 2004). For this reason, mutually independent indices should be selected (Schindler et al., 2008, 503).

By means of indicators in monitoring, dramatic changes in values can be detected and serve 
as an early warning, and as an indication of the necessity for deeper investigation, even if no specific limit values can be defined (Bock et al., 2005, 336). Landscape metrics may also be used to identify hot spots of biodiversity in rural Europe. Although they do not replace direct measurement of species biodiversity, these surveys can help make them more effective and less costly (Bailey et al., 2007, 472). Often mentioned as possible parameters are distribution, abundance and area proportions of land use types (e.g., Schüpbach et al., 1999, 212). Other aspects are the richness (number of land use types) and the uniformity of the landscape (Nagendra, 2002, 178).

\section{Indicator systems}

Due to the importance of landscape structure for biodiversity, there are currently a number of activities to develop indicators for monitoring biodiversity at the level of ecosystems or landscapes (EEA, 2007, 2005; BMU, 2007). Ideally, the same biodiversity indicators should be used at the global, national, regional and local level. However, this is not possible for practical reasons. The specific requirements for monitoring and for financial resources vary from country to country. Many monitoring systems have their own historical developments and even the methods for the same indicator differ from place to place (Strand et al., 2007, 17).

In Germany there are a number of indicator systems for monitoring land use change and biodiversity (see also Table 1):

- Indicators of Sustainable Development in Germany (Federal Government, 2002; Federal Statistical Office, 2010).

- The Core Environmental Indicator System of the German Federal Environmental Agency (Umweltbundesamt, 2007).

- Sustainable development indicators of the federal and state governments (LIKI indicators) (LIKI, 2011).

- Indicators of the national strategy on biological diversity (BMU, 2007).

However, there is still no complete and interoperable, nationwide monitoring system for biodiversity at the federal level. An earlier approach that could have served that purpose was so-called "ecological area sampling" (ökologische Flächenstichprobe) (Dröschmeister, 2001), whereby indicators of cultural influence and intensity of use, rarity or threat of habitats, and structural diversity were to be surveyed at the landscape and habitat levels in defined test areas (Hoffmann-Kroll et al., 1995, 595, see also Table 2). Complementarily, the Shannon Diversity and Evenness and the Fractal Dimension were proposed (Back et al., 1996, 21-33). Unfortunately, this concept was never fully implemented nationwide.

Stachow (1995) has proposed a system of indicators for monitoring agricultural landscape change. As a complex of factors important for the formation of communities, he mentions the natural conditions of the site (terrain, climate and soil type) and the type and intensity of human impact. The indicator system, therefore, is composed of three landscape indicators: the physical or natural diversity of landscapes, the diversity of land use, and the naturalness of land use. He starts from the assumption that increasing naturally the animation of the terrain is associated with an increase in various site conditions. Based on the criteria "length of contour lines in $\mathrm{m} / \mathrm{ha}$ per community", "height difference between the highest and lowest contour lines in the community", and "river length and area of surface waters", he arrives at statements regarding natural spatial diversity (Bork et al., 1995, 290). The variety of land use is identified based on the diversity of major land use types, length of forest fringes, field sizes and variety of crops within agricultural areas. The degree of naturalness is derived from natural conditions of sites, and the situation regarding crops (Bork et al., 1995, 292-293).

Living Reviews in Landscape Research

http://www. livingreviews.org/lrlr-2011-3 
Table 1: Selected indicators reliable to biodiversity and land use change in Germany and their use in the different indicator systems

\begin{tabular}{lcccc}
\hline $\begin{array}{l}\text { Indicator set / Institu- } \\
\text { tion }\end{array}$ & $\begin{array}{c}\text { Sustainable } \\
\text { develop- } \\
\text { ment in } \\
\text { Germany }\end{array}$ & $\begin{array}{c}\text { Core envi- } \\
\text { ronmental } \\
\text { indicators }\end{array}$ & $\begin{array}{c}\text { Indicators } \\
\text { of the } \\
\text { German } \\
\text { states }\end{array}$ & $\begin{array}{c}\text { National } \\
\text { strategy on } \\
\text { biodiversity }\end{array}$ \\
\hline $\begin{array}{l}\text { Dissection of the landscape } \\
\text { (Landscape fragmentation) }\end{array}$ & $\mathbf{x}$ & $\mathbf{x}$ & $\mathbf{x}$ \\
\hline Urban sprawl & $\mathbf{x}$ & $\mathbf{x}$ & $\mathbf{x}$ \\
\hline $\begin{array}{l}\text { Natura 2000 area designa- } \\
\text { tions }\end{array}$ & $\mathbf{x}$ & $\mathbf{x}$ & $\mathbf{x}$ \\
\hline $\begin{array}{l}\text { Size of strictly protected } \\
\text { areas }\end{array}$ & $\mathbf{x}$ & $\mathbf{x}$ & $\mathbf{x}$ & $\mathbf{x}$ \\
\hline $\begin{array}{l}\text { Land use: Increase in land } \\
\text { used for housing and trans- } \\
\text { port }\end{array}$ & $\mathbf{x}$ & $\mathbf{x}$ & $\mathbf{x}$ & $\mathbf{x}$ \\
\hline $\begin{array}{l}\text { Recreation areas } \\
\text { Species diversity and land- } \\
\text { scape quality }\end{array}$ & & & \\
\hline
\end{tabular}

A number of authors have emphasized the importance of landscape diversity as an indicator of species diversity in monitoring agricultural landscapes. In addition to land use practices, especially habitat heterogeneity plays an important part. It has often been noted that even using a few landscape and land use parameters, inferences can be made regarding large-scale patterns of species diversity (Benton et al., 2003; Tews et al., 2004; Billeter et al., 2008, 141-142).

In Germany, the avifauna is used as a nation-wide indicator of biological diversity at the species level (BMU, 2007; Sukopp, 2007). This indicator is contained both in the national set of sustainability indicators (Federal Government, 2002) and in the set of indicators for the national biodiversity strategy. For the calculation of the indicator, trends in the stocks of 59 selected bird species are recorded, representing the most important landscape and habitat types and land uses in Germany (agricultural land, forests, settlements, inland waters, coasts and seas, and the Alps). The size of the stocks should directly reflect the suitability of the landscape as a habitat for selected bird species. However, the condition of the landscape (structure and intensity of uses) is not registered.

In the case of landscape fragmentation by infrastructure, nationwide regular monitoring takes place. The German Federal Agency for Nature Conservation (BfN) regularly determines unfragmented open spaces equal to or larger than $100 \mathrm{sq}$. km. Also, "effective mesh size" $\mathrm{m}_{\text {eff }}$ (see above) has in recent years been applied in several German states, including Baden-Wurttemberg and Hesse, and is now established as a core indicator in the environmental system of indicators (LIKI, 2011).

At the European level, the European Environment Agency already in 2000 submitted a report on Landscape Diversity in the EU (EEA, 2000), in which landscape indicators for fragmentation, diversity or heterogeneity, and spatial arrangement and organisation of landscapes were used. The landscape metrics applied were: Patch Density (PD), Edge Density (ED), Perimeter/Area 
Table 2: Indicators of quality of landscape structure in the framework of spatial ecological sampling (Dierßen and Hoffmann-Kroll, 2004, 291-293).

\begin{tabular}{|c|c|c|}
\hline $\begin{array}{l}\text { Superordinate } \\
\text { issue }\end{array}$ & Special issue & Indicator \\
\hline \multirow{4}{*}{ Use intensity } & Naturalness / hemeroby & $\begin{array}{l}\text { Surface areas of natural and semi- } \\
\text { natural habitat types [in \%] }\end{array}$ \\
\hline & Degree of sealing & Proportion of sealed surface [in \%] \\
\hline & $\begin{array}{l}\text { Erosion risk caused by water, de- } \\
\text { pletion of arable soil }\end{array}$ & $\begin{array}{l}\text { Proportional area of arable land, } \\
\text { viticulture and intensive woody } \\
\text { plants with slope }>9 \%\end{array}$ \\
\hline & $\begin{array}{l}\text { Fragmentation and isolation of } \\
\text { habitats }\end{array}$ & $\begin{array}{l}\text { Total length of all roads }(5 \mathrm{~m} \\
\text { wide) outside of settlements [in } \\
\mathrm{m} / \mathrm{sq} . \mathrm{km} \text { ] }\end{array}$ \\
\hline \multirow{6}{*}{ Structural diversity } & $\begin{array}{l}\text { Habitat diversity / diversity of } \\
\text { living conditions }\end{array}$ & $\begin{array}{l}\text { Number of non-technical habitat } \\
\text { types per sq. km }\end{array}$ \\
\hline & Monotony of living conditions & $\begin{array}{l}\text { Average size of parcel of arable } \\
\text { land and vineyards [in ha] }\end{array}$ \\
\hline & $\begin{array}{l}\text { Density of linear refuges and } \\
\text { wildlife dispersion axis }\end{array}$ & $\begin{array}{l}\text { Length of linear elements/ edge } \\
\text { structures (hedges, forest belts, } \\
\text { tree rows, avenues, seams) per } \\
\text { sq. km }\end{array}$ \\
\hline & $\begin{array}{l}\text { Density of small habitats as } \\
\text { refuges and dispersal centres for } \\
\text { wild species }\end{array}$ & $\begin{array}{l}\text { Number of small habitats }(<400 \\
\text { sq. m) per sq. km } \\
\text { (tarns, ponds, springs, rocks, trees, } \\
\text { individual trees, small trees, etc.) }\end{array}$ \\
\hline & $\begin{array}{l}\text { Density of small-scale stepping } \\
\text { stones and network structures for } \\
\text { species with low range of action }\end{array}$ & $\begin{array}{l}\text { Mean number of quadrants per } \\
\text { sq. km, in which structural ele- } \\
\text { ments occur }\end{array}$ \\
\hline & Diversity of selected species groups & $\begin{array}{l}\text { Average number of bird or butter- } \\
\text { fly species per sq. km }\end{array}$ \\
\hline Rarity / threat & $\begin{array}{l}\text { Occurrence of rare and endangered } \\
\text { habitats of wildlife species }\end{array}$ & $\begin{array}{l}\text { Percentage of endangered habitat } \\
\text { types (according to Red List or } \\
\text { Habitat Directive) [in \%] }\end{array}$ \\
\hline
\end{tabular}


Ratio (PAR), Number of Classes (NC), Shannon's Diversity Index (SHDI), the Interspersion and Juxtaposition Index (IJI), and the Land Cover Diversity Index (LCDI).

As part of the EU project SPIN (Spatial Indicators for European Nature Conservation) (Bock et al., 2005), the potential of landscape metrics for pan-European nature conservation was explored, especially for the Natura 2000 network. Thereby, landscape metrics were applied, e.g., for the determination of the size of the ecologically effective protected areas. For this purpose, indices such as TCA/TCCA (total core area and total class core area), NCA (number of core areas) and CAI use (core area index) were used.

In a joint project for Cultural Landscape Research in Austria, landscape metrics were calculated nationwide (Wrbka, 2003). They have been used, for example, in the fields of landscape composition, habitat area, landscape configuration, ecological functions, habitat fragmentation, diversity and anthropogenic influence. For biodiversity monitoring in South Tyrol, five indicators were selected by experts to measure both heterogeneity of landscape structure and human impact (Tasser et al., 2008, 208). These include an index of landscape diversity (EEA, 2000), effective mesh size (Moser et al., 2007), hemeroby (Steinhardt et al., 1999), naturalness of near-river areas (adapted from Xiang, 1996) and agricultural intensity (UNEP, 2001). Tasser et al. (2008, 208) expanded this set by two indicators of species diversity: the area-weighted richness of vascular plants, and the frequency-weighted absolute species richness of vascular plants.

In the United States, the Heinz Center developed landscape indicators, of which eight refer to the landscape structure (Heinz Center, 2008). They are to be used to identify large-scale landscape patterns and human-induced landscape changes at the national level.

\section{Metrics for monitoring}

The monitoring of biodiversity is carried out almost solely at the level of species diversity, primarily on the basis of species richness, mostly using surrogate species or groups (especially birds and vascular plants). In the last few years, however, doubts as to the suitability of species or species groups for the estimation of biodiversity have increased. The criticism has concerned, in particular, conclusions drawn from the recording of species regarding the diversity of organisms of other taxa, or at other scales (spatial requirements etc.).

As a result, the focus has been directed towards the importance of landscape diversity for the expression of biological diversity. Increasingly, approaches and indicators for this level of biodiversity are being developed, especially for landscape diversity in agricultural and rural landscapes. It should be noted, however, that despite the presence of previous approaches, indicators of landscape and environmental diversity are not included in the indicator system of the United Nations, or in the German National Biodiversity Strategy. Here, there is a clear need to catch up.

Reference is often made to the potentials of remote sensing for cost-effective collection and presentation of landscape diversity. In particular, due to sophisticated sensor technology and resolution, as well as better availability of data, remote sensing, in combination with climate and environmental data, could lead to a more precise characterisation of landscape diversity, and thus a better assessment of species diversity.

Several examples from the great variety of landscape metrics found in the literature analysed have been compiled; these are repeatedly mentioned, or stand out as particularly significant (Table 3$)$.

It is obvious that landscape metrics must always be selected for different tasks or problems, and in accordance with the available resources. A single index, or always the same set of indices, is not automatically appropriate for all study objects. Similarly, because of their complexity, a combination of indices should generally be preferred to individual indices for the estimation of biodiversity. 
Table 3: Important landscape metrics in the field of biodiversity

\begin{tabular}{|c|c|c|}
\hline Function & Index & Source \\
\hline $\begin{array}{l}\text { Prediction and assessment } \\
\text { of biodiversity in landscape } \\
\text { mosaics of the agricultural } \\
\text { landscape }\end{array}$ & $\begin{array}{l}\text { (1) habitat diversity (number of habitat types } \\
\text { per unit area) } \\
\text { (2) habitat heterogeneity (number of habitat } \\
\text { patches, lengths of ecotones per landscape unit) } \\
\text { (3) portions of natural, semi-natural and inten- } \\
\text { sive land used }\end{array}$ & (Duelli, 1997, 88) \\
\hline Prediction of biodiversity & $\begin{array}{l}\text { Surface area of semi-natural ecosystems } \\
\text { Patch distribution, edge and patch density }\end{array}$ & $\begin{array}{l}\text { (Dramstad et al., 1996; Bote- } \\
\text { quilha Leitão et al., 2006, 11) } \\
\text { (Bailey et al., 2007, 466-467) }\end{array}$ \\
\hline $\begin{array}{l}\text { Prediction of species diver- } \\
\text { sity }\end{array}$ & $\begin{array}{l}\text { Patch Density PD, Largest Patch Index LPI, } \\
\text { Simpson's Diversity Index SIDI, Proximity } \\
\text { PROXMN, Patch Richness PR, Edge density } \\
\text { ED, Euclidean Nearest Neighbour ENNCV, Cir- } \\
\text { cumscribing Circle: CIRCMN } \\
\text { Number of species, population sizes, number of } \\
\text { viable populations and habitat area } \\
\text { Landscape diversity, intensity of agricultural } \\
\text { use, frequency weighted absolute species rich- } \\
\text { ness of vascular plants }\end{array}$ & $\begin{array}{l}\text { (Bailey et al., 2007, 466-467) } \\
\text { (Strand et al., 2007, 121) } \\
\text { (Tasser et al., 2008, 219) }\end{array}$ \\
\hline $\begin{array}{l}\text { Planning of biotope net- } \\
\text { works }\end{array}$ & $\begin{array}{l}\text { Proximity Index (allows assessment of individ- } \\
\text { ual patches depending on functional connection } \\
\text { with surrounding habitats) } \\
\text { Density of landscape elements, indices of con- } \\
\text { nectivity/ isolation }\end{array}$ & $\begin{array}{l}\text { (Kiel and Albrecht, 2004, 331) } \\
\text { (Baguette and Van Dyck, 2007, } \\
\text { 1125-1126) }\end{array}$ \\
\hline $\begin{array}{l}\text { Assessment of protected } \\
\text { areas, habitat requirements } \\
\text { of species of the core areas } \\
\text { and edges }\end{array}$ & $\begin{array}{l}\text { Total Core Area TCA, } \\
\text { Total Class Core Area TCCA, } \\
\text { Number of Core Areas NCA, } \\
\text { Core Area Index CAI, } \\
\text { Cority }\end{array}$ & (Bock et al., 2005) \\
\hline Landscape fragmentation & $\begin{array}{l}\text { Effective mesh size } \\
\text { Area of unfragmented open spaces }\end{array}$ & $\begin{array}{l}\text { (Jaeger, 2000) } \\
\text { (Lassen, 1979; Bundesamt für } \\
\text { Naturschutz, 2008) }\end{array}$ \\
\hline $\begin{array}{l}\text { Quantification of the floris- } \\
\text { tic diversity (habitat func- } \\
\text { tion) }\end{array}$ & $\begin{array}{l}\text { Shannon Diversity SHDI, } \\
\text { Number of different classes and their distribu- } \\
\text { tion }\end{array}$ & (Herbst et al., 2007) \\
\hline $\begin{array}{l}\text { Smallness, shape richness as } \\
\text { well as structuredness of a } \\
\text { landscape (natural spatial } \\
\text { diversity) }\end{array}$ & $\begin{array}{l}\text { Edge density ED, } \\
\text { Density of patch boundaries or linear elements } \\
\text { in a landscape } \\
\text { Length of contour lines per area, elevation dif- } \\
\text { ference between highest and lowest point, river } \\
\text { length and area of surface waters }\end{array}$ & $\begin{array}{l}\text { (Herbst et al., 2007) } \\
\text { (Stachow, 1995) }\end{array}$ \\
\hline Diversity of land use & $\begin{array}{l}\text { Diversity of main land use types, length of for- } \\
\text { est edges, field sizes }\end{array}$ & (Stachow, 1995) \\
\hline $\begin{array}{l}\text { Floristic species richness } \\
\text { (general) }\end{array}$ & $\begin{array}{l}\text { Distance (isolation) to usable habitat, largest } \\
\text { patch index LPI, patch size coefficient of varia- } \\
\text { tion PSCV }\end{array}$ & $\begin{array}{l}\text { (Grashof-Bokdam, 1997; Butaye } \\
\text { et al., 2001) } \\
\text { (Banko et al., 2000, 28) }\end{array}$ \\
\hline $\begin{array}{l}\text { Floristic species richness } \\
\text { (in natural ecosystems) }\end{array}$ & $\begin{array}{l}\text { Topographic and edaphic variables, in particular } \\
\text { slope direction and water balance } \\
\text { Shape complexity of the habitats }\end{array}$ & $\begin{array}{l}\text { (Burnett et al., 1998, 368) } \\
\text { (Honnay et al., 2003, 241-242) }\end{array}$ \\
\hline $\begin{array}{l}\text { Floristic species richness } \\
\text { (in landscapes) }\end{array}$ & $\begin{array}{l}\text { Surface area of land use, } \\
\text { Geometric landscape complexity, Number of } \\
\text { Shape Characterizing Points NSCP } \\
\text { Length of edges }\end{array}$ & $\begin{array}{l}\text { (Bastian and Haase, 1992, 27) } \\
\text { (Moser et al., 2002, 666) } \\
\text { (Bastian and Haase, 1992, 27) }\end{array}$ \\
\hline Faunal species richness & $\begin{array}{l}\text { Road density, forested area, distance to nearest } \\
\text { built-up area, density of human settlements, } \\
\text { degree of soil imperviousness }\end{array}$ & $\begin{array}{l}\text { (Sundell-Turner and Rodewald, } \\
2008,223 \text { ) }\end{array}$ \\
\hline
\end{tabular}




\section{Limitations}

Büchs et al. (2003) summarise limitations which occur in relation to the use of indicators for biodiversity monitoring. First, it must be noted that there is no indicator for biodiversity as a whole. Every aspect of biodiversity also requires its own indicator with very specific and well-defined characteristics, with agreed-upon definitions for their use (Tasser et al., 2008, 205). Furthermore, the classification of land use and habitat type mapping must be considered precisely. Default typifications may not necessarily be suitable for a specific question. Often, visually delimitable units are equated with functional structures and habitats (Filip et al., 2008, 534-535).

The indices used must also be questioned. In particular, the Shannon Index is used almost as a "standard" for large-scale landscape analysis (Filip et al., 2008, 536). However, it does not reflect the spatial distribution of classes, although this is crucial for the diversity of a landscape. "Thus, it is irrelevant to the result value of the index whether the landscape elements present a large area or a mosaic, even though this factor should be crucial for the diversity of a landscape." (Filip et al., 2008, 536). Moreover, even at the species level, the Shannon or the Simpson index is generally considered as not useful for large-scale monitoring of the integrity of biological diversity (Lamb et al., 2009, 439). Another problem, not only in the field of biodiversity, is that the selection of indicators is often driven by the availability of information. However, with respect to biodiversity, this can lead to delusive or adverse results (Failing and Gregory, 2003, 129).

A review of the literature makes it clear that a wide variety of indicators and systems is now available which are usually hardly comparable to one another. Especially in the field of sectoral indicators, a large number of other systems can be expected, which - and this seems to be an underlying trend - have been developed and used relatively independently of one another (Müller and Wiggering, 2004, 122).

\section{Conservation and management issues - landscape metrics for spatial planning and nature protection}

As shown above, the type of land use and the pattern of the landscape, the matrix, and also the arrangement of individual patches and their relative positions are crucial for the conservation of biological diversity. Land use changes in future will have one of the biggest effects on biodiversity, beside climate change (Sala et al., 2000). The management of land use patterns is therefore of great importance. Even in 1979, Haber wrote: "Spatial diversity should be accorded great importance in the planning process, as it identified the arrangement or 'mosaic' (pattern) of different, but similar spatial units or cells in a landscape ( $\gamma$-diversity)" (Haber, 1979, 21). As an overarching approach to planning, Forman $(1995,139)$ and others (Forman and Godron, 1986; Franklin and Forman, 1987; Turner, 1989) have suggested a so-called "aggregate-with-outliers" model. This means that areas used by humans should be aggregated as closely as possible, while small natural patches and corridors through developed areas are preserved. At the borders of the remaining large natural areas in the surroundings, human-used areas should be arranged as ever smaller and more distant islands. In their opinion, this model increases genetic diversity, provides a distribution of risk of strong interferences, and has other environmental benefits (Forman, 1995, 139-140). However, in already highly developed regions of the world, where nearly every place is subject to human use, such a model is hardly suitable. Therefore, Haber $(2008,95)$ proposes a land use pattern as slender and diverse as possible. In his opinion, this is the only promising approach for maintaining biodiversity, since land use change - along with climate change, with which it interacts - will have the greatest future impact on biodiversity (Haber, 2008, 95). Hence, he argues, it is necessary to reverse the homogenisation of land use, at least partially (Haber, 2003, 37). The goal of his concept of differentiated land use is to implement the objectives of nature and landscape 
conservation area-wide (Haber, 1989, 21). It provides that:

1. environmentally harmful, intensive land use not take $100 \%$ of the surface within a spatial unit, but should keep sufficient space available for relieving or buffering uses (10-15\%);

2. to avoid large, uniform surfaces, the prevailing land use be diversified in itself; this should apply both to agricultural land and to urban areas;

3. in an intensively used unit, at least $10 \%$ of the area be kept in, or developed to a "natureemphasized" state, as is possible with netlike distribution.

The issues raised under 1 and 3 could be partially identical, or overlap, but there are different objectives (Haber, 1998, 60). Other authors have adopted this concept, e.g., Buchwald (1982, Figure 2). He assigned protection categories to different landscape elements.

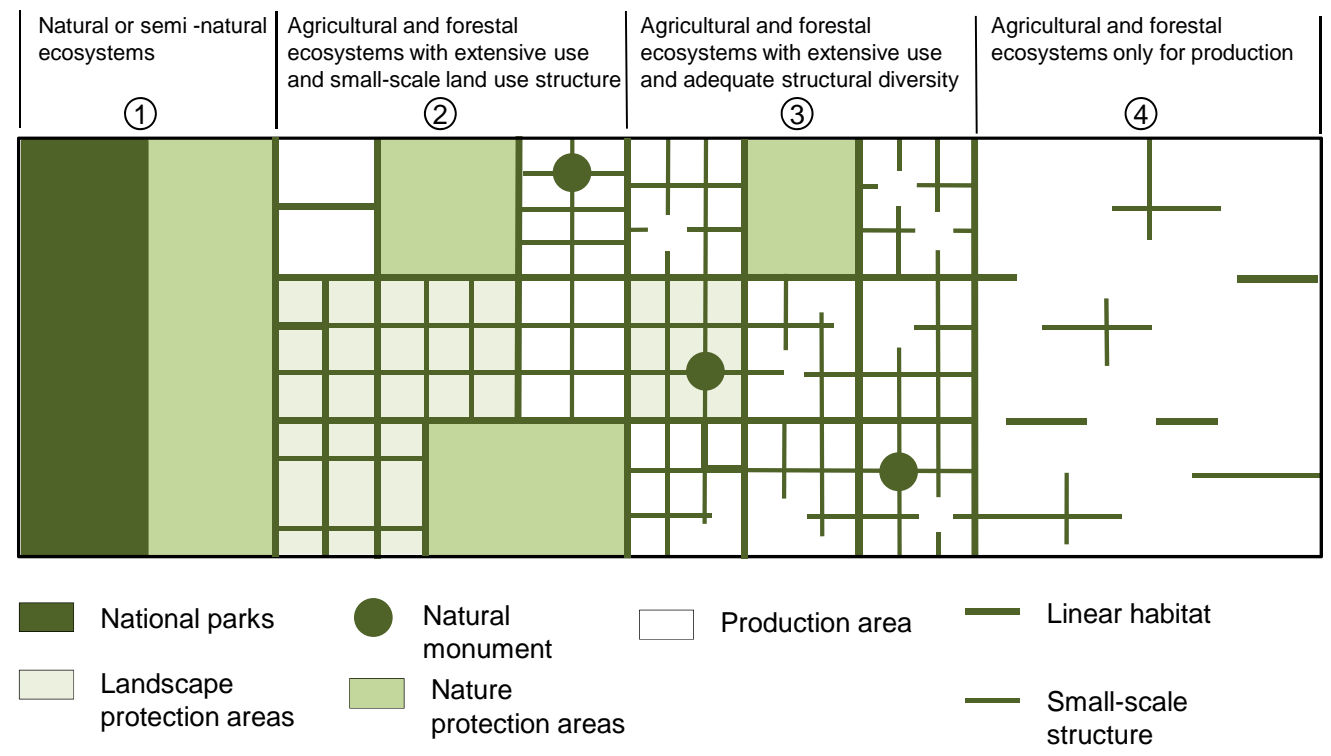

Figure 2: Differentiated agricultural land use. Adapted from Buchwald (1982, 103). In category 3, measures for structural enrichment are necessary.

This approach is also supported by the concept of a tiered target system of nature protection at $100 \%$ of the area (Plachter, 1991). There, Erz (1980) distinguishes four stages of the influence of nature conservation, ranging from strict nature reserves to extensively used areas and land which could be opened for additional intensive land use. On the latter, however, a minimum diversity of habitat conservation should be preserved by accompanying measures, or restored.

All these concepts emphasise the need to integrate the entire area of the landscape into the effort to maintain biodiversity. In this sense, dynamic conservation and development strategies for the cultural landscape must be found. More attention should be paid to ecosystem-specific development processes (succession) and spatial-functional aspects, as they play a key role, particularly for animals. Nevertheless, the designation of protected areas is evidently still necessary. They are included in the above concepts as a system of "core areas" for the protection of hard-torenew ecosystems, i.e., those with long development periods, and to preserve severely threatened elements of nature. But it is absolutely necessary to include the surrounding landscape. This

Living Reviews in Landscape Research

http://www. livingreviews.org/lrlr-2011-3 
means that there is not only a need for a large-scale ecological network (see below) outside of the core areas, but also for the preservation of a minimum share of small-scale structures. For example, in agricultural areas, field edge structures are particularly important as habitats for the preservation of biodiversity, both between the fields towards neighbouring areas with other land use types (Hietala-Koivu et al., 2004, 75). "A minimum of border structures amounting to at least $1-2 \%$ of the total agricultural land area can be justified on the basis of the data in the literature." (Knickel et al., 2001, 46). Also, the German Federal Nature Conservation Act (BNatschG, 2009) stipulates a minimum percentage of such elements $(\S 5(2)$ and $\S 20(6))$. One example is provided by the landscape framework plan in Mecklenburg-Western Pomerania, where regional minimum densities of landscape elements are defined (Müller et al., 2008). Using a GIS based on available digital data, regional densities of structures were determined and objectives for regional minimum densities per spatial unit were quantified. For approximately one third of the municipalities, an urgent need for the enrichment of landscape elements was ascertained.

\section{Conservation of nature}

What do the findings from these various studies mean for nature conservation? First, it is clear that the landscape level requires much more attention. Understanding the importance of the landscape matrix is important for the conservation of biological diversity. A variety of studies have shown that the protection of the widest possible diversity at the landscape level and a corresponding control of the development of the landscape matrix is more effective than the protection of individual species and habitats (Franklin, 1993). At the species level, however, it is difficult to develop general conservation strategies while managing a variety of species, as different demands on the vegetation or on landscape features and territorial claims often lead to conflicting objectives (Rey Benayas and de la Montaña, 2003, 365; Howell et al., 2000, 559). Against this background, there is a growing consensus that the landscape level is the most important level for the management of biodiversity. Conservation strategies must therefore be implemented at this scale to be successful (With, 2005, 240).

In a system of graded protection intensities of the entire landscape, protected areas certified as "core areas" are still important, but these should be designed to be significantly larger than is currently the case. So far, only a few reach the threshold of effective habitat size (Wiersma et al., 2004, 783; Schmitt, 2004, 94; Kaule and Henle, 1991, 17). Particularly in relation to possible changes that may result from climate change, the goal of protected areas should be to maintain as high as possible a level of ecosystem diversity, with a maximum of ecological gradients, and thus maximum biodiversity (Swenson and Franklin, 2000, 714; Juutinen et al., 2008, 3750-3751). The effectiveness of protected areas for the conservation of biological diversity is, however, affected not only by size but also, and essentially, by the landscape matrix of interdependent connectivity, and by human activity in the surrounding area (Franklin, 1993, 202; Wiersma et al., 2004, 773; With, 2005,240 ). Therefore, for the designation and management of protected areas, such factors at the landscape level as land use types and intensities, or landscape and habitat change in relation to the population density in and around the protected area, should be considered. In the surrounding landscape matrix, small and medium-sized areas located close together are needed (Franklin, 1993, 203). This it is not achievable only with protected areas, but must be considered in the context of the management of traditional agricultural and forestry systems outside of protected areas (Rey Benayas and de la Montaña, 2003, 366).

Opinions differ somewhat with respect to the importance of protecting natural spatial diversity. Although it is often argued that the protection of geomorphological heterogeneity could be an efficient strategy for the preservation of existing and potential biodiversity, it has been shown that this factor is closely linked to biodiversity in discontinuous landscapes (Nichols et al., 1998, 378). Especially in relation to long-term environmental change (e.g. climate change), landscapes with 
high geomorphological heterogeneity are considered important, since they have the potential for accommodating many plant communities, despite changing species composition (Burnett et al., 1998, 369). However, other voices warn against limiting efforts in protection of biodiversity only to achieving maximum possible landscape heterogeneity, as this would neglect the needs of specialised or endangered species. The high diversity of species in a heterogeneous landscape, it is argued, largely reflects the large number of generalists, which is then promoted by diversity-enhancing measures (Atauri and de Lucio, 2001, 157).

The different goals of protection of biodiversity can lead to conflicts with very real policy implications. Examples are the maintenance of ecological services, consideration of ethical principles, protection of single target species (e.g., "charismatic" large animals), the avoidance of aesthetic loss, or the protection and improvement of social and economic values. To address these problems, the goals must be described in detail, and matching indicators defined (Failing and Gregory, 2003, 123). For this purpose, specific landscape metrics can be applied to define minimum equipment numbers of the landscape. Examples include the Nature Protection Act in Germany (BNatschG, 2009) and state laws which demand the determination of structural minimum densities of landscape elements (see above), or, related to this, restrictions on the use of agricultural pesticides if minimum standards are not achieved (Enzian and Gutsche, 2004).

\section{Biotope networks}

One of the points of departure for the design of ecological networks is the assumption that the connection between landscape elements for the conservation of biological diversity can be at least as important as their size. Landscape structures that support the connectivity of species, biological communities and ecological processes are therefore a key element of conservation in a humanaltered environment (Bennett, 2003, 8). The importance of wild animal migration corridors for the protection and management of biodiversity is widely known (Hargrove et al., 2005, 361). Landscape elements in the open countryside can contribute effectively to the conservation of biodiversity as habitat islands if they are interconnected by corridors (Ahern, 1991, 139). For example, it was pointed out that connecting elements such as forest corridors or small forest patches serving as stepping stones can reinforce the distribution of species in the forest interior. The spread between the individual elements (patches) is crucial for the prevention of genetic stagnation in small populations (Noss, 1983, 703-704).

Again, however, the entire landscape matrix plays a significant role. Efforts to improve the connectivity of fragmented landscapes often focus on the remnants of natural and semi-natural habitats, and the distribution of stepping stones and corridors. However, it would often be more practical, and perhaps more effective, to reduce the virtual isolation of fragments by changing management practices in the surrounding matrix, e.g., by laying out corridor or stepping stone habitats (Ricketts, 2001, 97). Such networking is not necessary for all types, or in every case. Self-pollinating plant species have done without genetic exchange for eons. Studies by Öckinger and Smith $(2008,27)$ on the spread of insects also show that corridors do not necessarily have a positive effect, but that the quality of the surrounding matrix plays an important role. Even highly propagating species are relatively independent of such networking elements, as shown above.

Landscape metrics have been used to design ecological networks for quite some time. For example, indicators such as the density of landscapes elements, or metrics on connectivity or isolation, need to be stated for the configuration of landscapes. Baguette and Van Dyck (2007, 1125-1126) show that even simple measures can be beneficial landscape tools for the assessment of landscape connectivity. Nevertheless, they advocate cautious use in generalisation of the relationship between landscapes and species (Baguette and Van Dyck, 2007, 1125-1126). Kiel and Albrecht (2004, 331) recommend especially the proximity index for habitat network design, as it allows an assessment of individual areas in terms of functional integration with the living spaces of the surroundings.

Living Reviews in Landscape Research

http://www. livingreviews.org/lrlr-2011-3 


\section{Metrics in planning and nature protection}

The successful protection of biodiversity requires the preservation of adequate habitats and ecosystem functioning in the context of the entire landscape complex at various spatial and temporal scales. Particularly in light of future land use changes - which will increase further - and expected climate change, landscapes with high geomorphological heterogeneity are considered important. Therefore, in planning and nature conservation, the landscape level needs much more attention than has been the case to date. An understanding of the importance of the landscape matrix and an appropriate management are important for maintaining diversity.

Protected areas should still be included in the strategy; however, they should be designated as much larger areas than before. Above all, more emphasis should be placed on their contribution to ecosystem diversity and thus a maximum of possible (potential) species diversity. The selection of protected areas, therefore, must not only focus on endangered species.

Outside of protected areas, the management of traditional agricultural and forestry systems remains a key element of nature conservation. The consideration of the entire landscape matrix should also include the preservation or development of a functioning mosaic of interconnected habitats as an ecological network associated with areas of intermediate intensity cultivation (agriculture, settlement, etc.), with a minimum number or density of small-scale, semi-natural landscape elements.

In this area, landscape metrics can help improve the theoretical foundation of the methods of landscape planning and their practical application, with the goal of sustainability (Botequilha Leitão and Ahern, 2002, 65). Examples of the use of landscape metrics in spatial planning can be found in landscape planning, in the design of ecological networks and in nature conservation. Landscape metrics can thus be used for the selection of protected areas (Sundell-Turner and Rodewald, 2008; Harrison and Fahrig, 1995), the evaluation of the landscape (Botequilha Leitão et al., 2006; Herbst, 2007), or the analysis of equipment deficiencies of the landscape (Müller et al., 2008) (see below). For example, Herbst et al. (2007, 236) examined landscape metrics for usefulness as an assessment tool in strategic landscape planning. In the range of species and communities, particularly the measures Shannon-Diversity and Edge Density were found to be useful.

\section{Conclusions}

Due to increasing demand and intensification of land use by humans, land use changes are expected to be the most significant driver of change in biological diversity in future (Sala et al., 2000, 1772). Against this background, it seems all the more important to explore the relationships between land use structure and biological diversity, and to understand the consequences of different landscape patterns for the composition and diversity of plant and animal species. On this basis, alternatives for the design of the landscape can - and must - be developed (Brosofske et al., 1999, 214).

In the context of biodiversity, landscape metrics can be used to assess landscape patterns, to define the minimum equipment, to carry out isolation or connectivity analysis and to recognise and monitor the results in changing landscapes. Moreover, landscape metrics have come to play a considerable role in the analysis and assessment of biodiversity, especially in local studies of species distribution and modelling, analysing and characterising the diversity of landscapes (as part of biodiversity), and for monitoring. It can be stated that:

- Landscape metrics are applied in a variety of local studies and research projects. Only a few indices are used constantly in different studies. Thus, there is a lack of comparability of studies and problems in the formation of general statements.

- Landscape metrics are already used in monitoring, but there is no "standard set" of landscape metrics which is frequently used. 
- Usually very simple measures are used, especially for planning purposes, because they are more demonstrative and more accessible to the public.

- In studies a large number of numerical values are often generated, but it should be kept in mind that many landscape metrics are highly correlated.

- Usually temporal dynamics are not considered, or not sufficiently considered. The ecological significance of a measured pattern is difficult to assess without an understanding of the historical variability of that pattern.

- Vertical complexity is too little considered. However, it can be important for habitat modelling (e.g., for birds). Some developments are currently in progress (McGarigal and Cushman, 2005; Hoechstetter, 2009; Hoechstetter et al., 2011), but further developments on ecological transitions and vertical structures appear necessary.

- A comprehensive overall view on the state of research is lacking.

Often, one finds only very general statements on the relationship between landscape structure and biological diversity. Generally, there is still a deficit in converting findings about individual species to general knowledge about the relationship between landscape structure and biodiversity (Turner, 2005, 331). The evaluation and prediction of species richness in complex landscapes remains a problem, because there is no simple scaling function of species diversity in a heterogeneous environment (Wagner and Edwards, 2001, 121). At the species level, it is also difficult to postulate a general correlation between biodiversity and landscape parameters (Brotons and Rosell, 2001). Hence, for certain species, only land use is crucial; for others, the landscape structure in terms of relationships to neighbouring land uses or edge lengths of hedges, etc. are important (see also, e.g., Burel et al., 1998; Zebisch, 2002, 5). Moreover, the potential value of an area for conservation of biological diversity from the perspective of nature conservation does not depend on how many species are present, but rather which ones (Wagner and Edwards, 2001, 121). In addition, qualities of biodiversity which are recordable by landscape metrics are only a part of the reality. Biodiversity objectives should also be set on the basis of non-measurable qualities, such as natural beauty, wilderness and perceptibility of a landscape (Weinzierl, 2004, 20).

Overall, it can be stated that the possibilities for the application of indices of landscape structure for spatial planning and for environmental and nature conservation have not been fully exhausted. Since they are suitable as indicators of processes of land use development and environmental status, such indices should more than ever find their way into spatial environment monitoring and information systems.

\section{Acknowledgements}

The author thanks Ms. Jürgens for her support in the extensive literature review, and Mr. Wende for the review of the manuscript (both of the Leibniz Institute of Ecological Urban and Regional Development). 


\section{References}

Ahern, J. (1991), "Planning for an extensive open space system: linking landscape structure and function", Landscape and Urban Planning, 21(1-2): 131-145, [DOI]. (Cited on page 20.)

Atauri, J.A. and de Lucio, J.V. (2001), "The role of landscape structure in species richness distribution of birds, amphibians, reptiles and lepidopterans in Mediterranean landscapes", Landscape Ecology, 16(2): 147-159, [DOI]. (Cited on page 20.)

Back, H.-E., Rohner, M.-S., Seidling, W. and Willecke, S. (1996), Konzepte zur Erfassung und Bewertung von Landschaft und Natur im Rahmen der 'ökologischen Flächenstichprobe', Fachserie 19, Reihe 6, Wiesbaden (Statistisches Bundesamt). (Cited on page 12.)

Baguette, M. and Van Dyck, H. (2007), "Landscape connectivity and animal behavior: functional grain as a key determinant for dispersal", Landscape Ecology, 22(8): 1117-1129, [DOI]. (Cited on pages 16 and 20.)

Bailey, D., Billeter, R., Aviron, S., Schweiger, O. and Herzog, F. (2007), "The influence of thematic resolution on metric selection for biodiversity monitoring in agricultural landscapes", Landscape Ecology, 22(3): 461-473, [DOI]. (Cited on pages 9, 11, 12, and 16.)

Baldwin, D.J.B., Weaver, K., Schnekenburger, F. and Perera, A.H. (2004), "Sensitivity of landscape pattern indices to input data characteristics on real landcapes: Implications for their use in natural disturbances emulation", Landscape Ecology, 19(3): 255-271. (Cited on page 7.)

Banko, G., Schneider, W., Wrbka, T., Schmitzberger, I. and Estreguil, C. (2000), "Einsatz von Fernerkundungs- und GIS-Methoden zur Charakterisierung Europäischer Landschaften unter dem Aspekt der Erhaltung der Biodiversität", in Strobl, J., Blaschke, T. and Griesebner, G., eds., Angewandte Geographische Informationsverarbeitung XII, Beiträge zum AGIT-Symposium, Salzburg 2000, pp. 24-29, Heidelberg (Wichmann). (Cited on page 16.)

Bastian, O. and Haase, G. (1992), "Zur Kennzeichnung des biotischen Regulationspotentials im Rahmen von Landschaftsdiagnosen", Zeitschrift für Ökologie und Naturschutz, 1(1): 23-34. (Cited on pages 8 and 16.)

Bennett, A.F. (2003), Linkages in the Landscape: The Role of Corridors and Connectivity in Wildlife Conservation, Conserving Forest Ecosystems Series, 1, Gland; Cambridge (IUCN). Google Books. (Cited on page 20.)

Benton, T.G., Vickery, J.A. and Wilson, J.D. (2003), "Farmland biodiversity: is habitat heterogeneity the key?", Trends in Ecology \& Evolution, 18(4): 182-188, [DOI]. (Cited on page 13.)

Billeter, R., Liira, J., Bailey, S., Bugter, R., Arens, P., Augenstein, I., Aviron, S., Baudry, J., Bukacek, R., Burel, F., Cerny, M., De Blust, G., De Cock, R., Diekötter, T., Dietz, H., Dirksen, J., Dormann, C., Durka, W., Frenzel, M., Hamersky, R., Hendrickx, F., Herzog, F., Klotz, S., Koolstra, B., Lausch, A., Le Coeur, D., Maelfait, J., Opdam, P., Roubalova, M., Schermann, A., Schermann, N., Schmidt, T., Schweiger, O., Smulders, M., Speelmans, M., Simova, P., Verboom, J., van Wingerden, W., Zobel, M. and Edwards, P. (2008), "Indicators for biodiversity in agricultural landscapes: a pan-European study", Journal of Applied Ecology, 45(1): 141-150. (Cited on page 13.)

Bissonette, J.A., ed. (1997), Wildlife and Landscape Ecology: Effects of Pattern and Scale, New York (Springer). Google Books. (Cited on page 7.) 
Blab, J., Klein, M. and Ssymank, A. (1995), "Biodiversität und ihre Bedeutung in der Naturschutzarbeit", Natur und Landschaft, 70(1): 11-18. (Cited on page 6.)

Blaschke, T. (2000), "Landscape metrics: Konzepte eines jungen Ansatzes der Landschaftsökologie und Anwendungen in Naturschutz und Landschaftsforschung", Archiv für Naturschutz und Landschaftsforschung, 39: 267-299. (Cited on page 5.)

Blaschke, T., Tiede, D. and Heurich, M. (2004), "3D-landscape metrics to modelling forest structure and diversity based on laser-scanning data", in Thies, M., Koch, B., Spiecker, H. and Weinacker, H., eds., Laser-Scanners for Forest and Landscape Assessment, Proceedings of the ISPRS working group VIII/2, Freiburg, Germany, 3-6 October 2004, ISPRS Archives, XXXVI, Part 8/W2, pp. 129-132, Freiburg (Albert Ludwigs University). Online version (accessed 25 October 2011):

http://www.isprs.org/proceedings/XXXVI/8-W2/. (Cited on page 7.)

BMU (2007), "National Strategy on Biological Diversity: Adopted by the Federal Cabinet on 7 November 2007", Küchler-Krischun, J. and Walter, A.M. [BMU], eds., BMU Brochure, Berlin (Federal Ministry for the Environment, Nature Conservation and Nuclear Safety). Online version (accessed 12 October 2011):

http://www.bmu.de/english/nature/downloads/doc/41253.php. (Cited on pages 12 and 13.)

BNatschG (2009), "Gesetz zur Neuregelung des Rechts des Naturschutzes und der Landschaftspflege", Bundesgesetzblatt I, pp. 2542-2579, Nr. 51, Köln (Bundesanzeiger Verlag). Online version (accessed 25 October 2011):

http://www.bgbl.de/Xaver/start.xav?startbk=Bundesanzeiger_BGBl. (Cited on pages 19 and 20.)

Bock, M., Rossner, G., Wissen, M., Remm, K., Langanke, T., Lang, S., Klug, H., Blaschke, T. and Vrščaj, B. (2005), "Spatial indicators for nature conservation from European to local scale", Ecological Indicators, 5(4): 322-338, [DOI]. (Cited on pages 12, 15, and 16.)

Bolliger, J., Wagner, H.H. and Turner, M.G. (2007), "Identifying and Quantifying Landscape Patterns in Space and Time", in Kienast, F., Wildi, O. and Ghosh, S., eds., A Changing World: Challenges for Landscape Research, Landscape Series, 8, pp. 177-194, Berlin (Springer), [DOI]. (Cited on pages 5 and 7.)

Bork, H.-R., Dalchow, C., Kächele, H., Piorr, H.-P. and Wenkel, K.-O. (1995), Agrarlandschaftswandel in Nordost-Deutschland unter veränderten Rahmenbedingungen: Ökologische und ökonomische Konsequenzen, Berlin (Ernst und Sohn). (Cited on page 12.)

Botequilha Leitão, A. and Ahern, J. (2002), "Applying landscape ecological concepts and metrics in sustainable landscape planning", Landscape and Urban Planning, 59(2): 65-93, [DOI]. (Cited on pages 5 and 21.)

Botequilha Leitão, A., Miller, J., Ahern, J. and McGarigal, K. (2006), Measuring Landscapes: A Planner's Handbook, Washington, DC (Island Press). (Cited on pages 11, 16, and 21.)

Brosofske, K.D., Chen, J., Crow, T.R. and Saunders, S.C. (1999), "Vegetation responses to landscape structure at multiple scales across a Northern Wisconsin, USA, pine barrens landscape", Plant Ecology, 143: 203-218, [DOI]. (Cited on pages 8 and 21.)

Brotons, L. and Rosell, C. (2001), "Identifying asymmetries in landscape use at different scales by forest birds and mammals: a tool for ecological planning and corridor design", in Mander,

Living Reviews in Landscape Research

http://www. livingreviews.org/lrlr-2011-3 
Ü., Printsmann, A. and Palang, H., eds., Development of European Landscapes, Publicationes Instituti Geographici Universitatis Tartuensis, 92, pp. 565-566, Tartu (University of Tartu). (Cited on page 22.)

Büchs, W., Harenberg, A., Zimmermann, J. and Weiß, B. (2003), "Biodiversity, the ultimate agri-environmental indicator? Potential and limits for the application of faunistic elements as gradual indicators in agroecosystems", Agriculture, Ecosystems \&3 Environment, 98: 99-123, [DOI]. (Cited on page 17.)

Buchwald, K. (1982), "Die natürliche Umwelt des Menschen sichern: Landschaft und Landschaftsschutz in der industriellen Gesellschaft", Der Bürger im Staat, 32(2): 99-107. (Cited on page 18.)

Bundesamt für Naturschutz (2008), "Daten zur Natur 2008", Münster (Landwirtschaftsverlag). (Cited on pages 9 and 16.)

Burel, F., Baudry, J., Butet, A., Clergeau, P., Delettre, Y., Le Coeur, D., Dubs, F., Morvan, N., Paillat, G., Petit, S., Thenail, C., Brunel, E. and Lefeuvre, J.-C. (1998), "Comparative biodiversity along a gradient of agricultural landscapes", Acta Oecologica, 19(1): 47-60, [DOI]. (Cited on page 22.)

Burnett, M.R., August, P.V., Brown Jr, J.H. and Killingbeck, K.T. (1998), "The Influence of Geomorphological Heterogeneity on Biodiversity. I. A Patch-Scale Perspective", Conservation Biology, 12(2): 363-370, [DOI]. (Cited on pages 8, 10, 16, and 20.)

Butaye, J., Jacquemyn, H. and Hermy, M. (2001), "Differential colonization causing non-random forest plant community structure in a fragmented agricultural landscape", Ecography, 24(4): 369-380, [DOI]. (Cited on pages 8 and 16.)

Cain, D.H., Riitters, K.H. and Orvis, K. (1997), "A multi-scale analysis of landscape statistics", Landscape Ecology, 12(4): 199-212, [DOI]. (Cited on page 11.)

Cardillo, M., Macdonald, D.W. and Rushton, S.P. (1999), "Predicting mammal species richness and distributions: testing the effectiveness of satellite-derived land cover data", Landscape Ecology, 14(5): 423-435, [DOI]. (Cited on page 11.)

Castilla, G., Larkin, K., Linke, J. and Hay, G. (2009), "The impact of thematic resolution on the patch-mosaic model of natural landscapes", Landscape Ecology, 24(1): 15-23, [DOI]. (Cited on page 7.)

Corry, R.C. (2005), "Characterizing fine-scale patterns of alternative agricultural landscapes with landscape pattern indices", Landscape Ecology, 20(5): 591-608, [DOI]. (Cited on page 7.)

Dale, V.H., Brown, S., Haeuber, R.A., Hobbs, N.T., Huntly, N., Naiman, R.J., Riebsame, W.E., Turner, M.G. and Valone, T.J. (2000), "Ecological principles and guidlines for managing the use of land", Ecological Applications, 10(3): 639-670. (Cited on page 11.)

Deutschewitz, K. (2001), Landschaftsstruktur und Verbreitungsmuster invasiver Pflanzengruppen, Diploma Thesis, Universität Potsdam, Potsdam. Online version (accessed 12 October 2011): http://www.ufz.de/data/lausch_deutschewitz_diplom15556248.pdf. (Cited on pages 8, 9, and 11.)

Dierßen, K. and Hoffmann-Kroll, R. (2004), "Naturschutzziele, Naturschutzplanung und Indikatoren für den Zustand der Natur aus der Ökologischen Flächenstichprobe", in Wiggering, H. and Müller, F., eds., Umweltziele und Indikatoren: Wissenschaftliche Anforderungen an ihre Festlegung und Fallbeispiele, Geowissenschaften + Umwelt, pp. 267-308, Berlin (Springer). (Cited on page 14.) 
Dormann, C.F., Blaschke, T., Lausch, A., Schröder, B. and Söndgerath, D., eds. (2004), Habitatmodelle - Methodik, Anwendung, Nutzen, Tagungsband zum Workshop, Leipzig, 8. - 10. Oktober 2003, UFZ-Berichte, 9/2004, Leipzig (UFZ Leipzig-Halle). Online version (accessed 12 October 2011):

http://www.ufz.de/index.php?de=5901. (Cited on pages 7 and 10.)

Dorner, B., Lertzman, K. and Fall, J. (2002), "Landscape pattern in topographically complex landscapes: issues and techniques for analysis", Landscape Ecology, 17(8): 729-743, [DOI]. (Cited on page 7. )

Dramstad, W.E., Olson, J.D. and Forman, R.T.T. (1996), Landscape Ecology Principles in Landscape Architecture and Land-Use Planning, Washington, D.C. (Island Press). (Cited on pages 11 and 16.)

Dröschmeister, R. (2001), "Bundesweites Naturschutzmonitoring in der "Normallandschaft" mit der Ökologischen Flächenstichprobe", Natur und Landschaft, 76(2): 58-69. (Cited on page 12.)

Duelli, P. (1997), "Biodiversity evaluation in agricultural landscapes: An approach at two different scales", Agriculture, Ecosystems 86 Environment, 62: 81-91, [DOI]. (Cited on pages 9, 11, and 16.)

Dufour, A., Gadallah, F., Wagner, H.H., Guisan, A. and Buttler, A. (2006), "Plant species richness and environmental heterogeneity in a mountain landscape: effects of variability and spatial configuration", Ecography, 29(4): 573-584, [DOI]. (Cited on page 7.)

EEA (2000), "From Land Cover to Landscape Diversity in the European Union", Brussels (European Commission). Online version (accessed 25 October 2011): http://ec.europa.eu/agriculture/publi/reports/. (Cited on pages 13 and 15.)

EEA (2005), "Agriculture and environment in EU-15 - the IRENA indicator report", EEA Report, 6/2005, Copenhagen (European Environment Agency). Online version (accessed 25 October 2011):

http://www.eea.europa.eu/publications/eea_report_2005_6. (Cited on page 12.)

EEA (2007), "Halting the loss of biodiversity by 2010: proposal for a first set of indicators to monitor progress in Europe", Technical Report, 11/2007, Copenhagen (European Environment Agency). Online version (accessed 25 October 2011):

http://www.eea.europa.eu/publications/technical_report_2007_11. (Cited on page 12.)

Enzian, S. and Gutsche, V. (2004), "GIS-gestützte Berechnung der Ausstattung von Agrarräumen mit naturnahen terrestrischen Biotopen auf der Basis der Gemeinden - 2. Ausgabe des Verzeichnisses der regionalisierten Kleinstrukturanteile", Nachrichtenblatt des Deutschen Pflanzenschutzdienstes, 56(12): 299-308. (Cited on page 20.)

Ernoult, A., Bureau, F. and Poudevigne, I. (2003), "Patterns of organisation in changing landscapes", Landscape Ecology, 18: 239-251, [DOI]. (Cited on page 7.)

Erz, W. (1980), "Naturschutz - Grundlagen, Probleme und Praxis", in Buchwald, K. and Engelhardt, W., eds., Handbuch für Planung, Gestaltung und Schutz der Umwelt, Vol.3: Die Bewertung und Planung der Umwelt, pp. 560-637, München; Wien (BLV Verlagsgesellschaft). (Cited on page 18.)

Failing, L. and Gregory, R. (2003), "Ten common mistakes in designing biodiversity indicators for forest policy", Journal of Environmental Management, 68(2): 121-132, [DOI]. (Cited on pages 17 and 20.)

Living Reviews in Landscape Research

http://www. livingreviews.org/lrlr-2011-3 
Faith, D.P., Carter, G., Cassis, G., Ferrier, S. and Wilkie, L. (2003), "Complementarity, biodiversity viability analysis, and policy-based algorithms for conservation", Environmental Science $\&$ Policy, 6(3): 311-328, [DOI]. (Cited on page 11.)

Fauth, P.T., Gustafson, E.J. and Rabenold, K.N. (2000), "Using landscape metrics to model source habitat for Neotropical migrants in the midwestern U.S.", Landscape Ecology, 15(7): 621-631, [DOI]. (Cited on page 10.)

Fearer, T.M. and Stauffer, D.F. (2003), "Relationship of ruffed grouse (Bonasa umbellus) home range size to landscape characteristics", American Midland Naturalist, 150(1): 104-114, [DOI]. (Cited on page 9.)

Federal Government (2002), "Perspektives for Germany: Our Strategy for Sustainable Development", Berlin (Presse- und Informationsamt der Bundesregierung). URL (accessed 12 October 2011):

http://www . bundesregierung.de/Webs/Breg/nachhaltigkeit/DE/Berichte/Berichte .

html. (Cited on pages 12 and 13.)

Federal Statistical Office (2010), "Sustainable Development in Germany: Indicator Report 2010", Wiesbaden (Federal Statistical Office). Online version (accessed 25 October 2011): http://www.destatis.de/publikationen. (Cited on page 12.)

Feest, A., Aldred, T.D. and Jedamzik, K. (2010), "Biodiversity quality: A paradigm for biodiversity", Ecological Indicators, 10(6): 1077-1082, [DOI]. (Cited on page 11.)

Fernández, N., Delibes, M. and Palomares, F. (2007), "Habitat-related heterogeneity in breeding in a metapopulation of the Iberian lynx", Ecography, 30(3): 431-439, [DOI]. (Cited on pages 9 and 10.)

Filip, C., Pietsch, M. and Richter, K. (2008), "Biotoptypenvielfalt = Lebensraumvielfalt?: Eine kritische Beleuchtung GIS-gestützter Raumdiversitätsanalysen aus artengruppenspezifischer Sicht", in Strobl, J., Blaschke, T. and Griesebner, G., eds., Angewandte Geoinformatik 2008, Beiträge zum 20. AGIT-Symposium, Salzburg, 2.-4. Juli 2008, pp. 534-543, Heidelberg (Wichmann). (Cited on page 17.)

Forman, R.T.T. (1995), "Some general principles of landscape and regional ecology", Landscape Ecology, 10(3): 133-142, [DOI]. (Cited on page 17.)

Forman, R.T.T. and Godron, M. (1986), Landscape Ecology, New York (Wiley). (Cited on page 17.)

Franklin, J.F. (1993), "Preserving biodiversity: Species, ecosystems or landscapes", Ecological Applications, 3(2): 202-205, [DOI]. (Cited on page 19.)

Franklin, J.F. and Forman, R.T.T. (1987), "Creating landscape patterns by forest cutting: Ecological consequences and principles", Landscape Ecology, 1(1): 5-18, [DOI]. (Cited on page 17.)

Gorresen, P.M. and Willig, M.R. (2004), "Landscape Responses of Bats to Habitat Fragmentation in Atlantic Forest of Paraguay", Journal of Mammalogy, 85(4): 688-697, [DOI]. (Cited on page 9.)

Grashof-Bokdam, C. (1997), "Forest species in an agricultural landscape in the Netherlands: Effects of habitat fragmentation", Journal of Vegetation Science, 8(1): 21-28, [DOI]. (Cited on pages 8 and 16.) 
Grillmayer, R. (2000), "Satellitenbildgestützte Analyse der Landschaftsstruktur für die Habitatbewertung des Steinkauzes", in Strobl, J., Blaschke, T. and Griesebner, G., eds., Angewandte geographische Informationsverarbeitung XII, Beiträge zum AGIT-Symposium, Salzburg 2000, pp. 202-209, Heidelberg (Wichmann). (Cited on page 10.)

Groom, G., Mücher, C., Ihse, M. and Wrbka, T. (2006), "Remote Sensing in Landscape Ecology: Experiences and Perspectives in a European Context", Landscape Ecology, 21(3): 391-408, [DOI]. (Cited on page 7.)

Haber, W. (1979), "Theoretische Anmerkungen zur 'Ökologischen Planung", Verhandlungen der Gesellschaft für Ökologie, 7: 19-29. (Cited on page 17.)

Haber, W. (1989), "Differenzierte Bodennutzung im Siedlungsraum", disP - The Planning Review, 25(99): 18-21. (Cited on page 18.)

Haber, W. (1998), "Das Konzept der differenzierten Landnutzung: Grundlage für Naturschutz und nachhaltige Naturnutzung", in Klingenstein, F., ed., Ziele des Naturschutzes und einer nachhaltigen Naturnutzung in Deutschland, Tagungsband zum Fachgespräch, Bonn, 24. und 25. März 1998, pp. 57-64, Bonn (BMU). (Cited on page 18.)

Haber, W. (2003), Biodiversität: Ein neues Leitbild und seine Umsetzung in die Praxis, Dresden (Sächsische Landesstiftung Natur und Umwelt). Online version (accessed 25 October 2011): http://www.lanu.de/media/public/lanu_publications/35_Biodiversitaet_Haber_ Brosch_web.pdf. (Cited on page 17.)

Haber, W. (2008), "Biological Diversity - a Concept Going Astray?", GAIA, 17(S1): 91-96. (Cited on page 17.)

Haines-Young, R.H. (2009), "Land use and biodiversity relationships: Land Use Futures", Land Use Policy, 26(Supplement 1): S178-S186, [DOI]. (Cited on page 5.)

Hamer, T.L., Flather, C.H. and Noon, B.R. (2006), "Factors associated with grassland bird species richness: the relative roles of grassland area, landscape structure, and prey", Landscape Ecology, 21(4): 569-583, [DOI]. (Cited on page 10.)

Hargrove, W.W., Hoffman, F.M. and Efroymson, R.A. (2005), "A Practical Map-Analysis Tool for Detecting Potential Dispersal Corridors", Landscape Ecology, 20(4): 361-373, [DOI]. (Cited on page 20.)

Harrison, S. and Fahrig, L. (1995), "Landscape pattern and population conservation", in Hansson, L., Fahrig, L. and Merriam, G., eds., Mosaic Landscapes and Ecological Processes, IALE Studies in Landscape Ecology, 2, pp. 293-308, London (Chapman \& Hall). Google Books. (Cited on page 21.)

Heino, J. (2010), "Are indicator groups and cross-taxon congruence useful for predicting biodiversity in aquatic ecosystems?", Ecological Indicators, 10(2): 112-117, [DOI]. (Cited on page 11.)

Heinz Center (2008), "Landscape Pattern Indicators for the Nation: A Report from the Heinz Center's Landscape Pattern Task Group", Washington, DC (The H. John Heinz III Center for Science, Economics and the Environment). Online version (accessed 25 October 2011): http://www.heinzctr.org/Major_Reports.html. (Cited on pages 5 and 15.)

Herbst, H. (2007), Verwendbarkeit von Landschaftsstrukturmaßen als Bewertungsinstrument in der Landschaftsrahmenplanung: Das Beispiel Landschaftsrahmenplan Havelland, Diploma Thesis, TU Berlin, Berlin. Online version (accessed 12 October 2011):

Living Reviews in Landscape Research

http://www. livingreviews.org/lrlr-2011-3 
http://www.geoinformation.tu-berlin.de/index.php?id=149\&L=0\&type=1. (Cited on page 21.)

Herbst, H., Förster, M., Uehlein, U. and Kleinschmit, B. (2007), "Verwendbarkeit von Landschaftsstrukturmaßen als Bewertungsinstrument in der Landschaftsrahmenplanung", in Strobl, J., Blaschke, T. and Griesebner, G., eds., Angewandte Geoinformatik 200\%, Beiträge zum 19. AGIT Symposium Salzburg, 4.-6. Juli 2007, pp. 234-239, Heidelberg (Wichmann). (Cited on pages 16 and 21.)

Hietala-Koivu, R., Lankoskib, J. and Tarmi, S. (2004), "Loss of biodiversity and its social cost in an agricultural landscape", Agriculture, Ecosystems \& Environment, 103(1): 75-83, [DOI]. (Cited on page 19.)

Hobbs, E.R. (1988), "Species richness of urban forest patches and implications for urban landscape diversity", Landscape Ecology, 1(3): 141-152, [DOI]. (Cited on page 8.)

Hoechstetter, S. (2009), Enhanced methods for analysing landscape structure: Landscape metrics for characterising three-dimensional patterns and ecological gradients, Ph.D. Thesis, TU Dresden, Dresden. (Cited on page 22.)

Hoechstetter, S., Walz, U., Le Dang, H. and Thinh, N.X. (2008), "Effects of topography and surface roughness in analyses of landscape structure - A proposal to modify the existing set of landscape metrics", Landscape Online, 3: 1-14, [DOI]. (Cited on page 7.)

Hoechstetter, S., Walz, U. and Thinh, N.X. (2011), "Adapting lacunarity techniques for gradientbased analyses of landscape surfaces", Ecological Complexity, 8(3): 229-238, [DOI]. (Cited on page 22.)

Hoffmann-Kroll, R., Schäfer, D. and Seibel, S. (1995), "Indikatorensystem für den Umweltzustand in Deutschland", Wirtschaft und Statistik, 1995(8): 589-597. (Cited on page 12.)

Honnay, O., Hermy, M. and Coppin, P. (1999), "Effects of area, age and diversity of forest patches in Belgium on plant species richness, and implications for conservation and reforestation", Biological Conservation, 87(1): 73-84, [DOI]. (Cited on page 8.)

Honnay, O., Piessens, K., Van Landuyt, W., Hermy, M. and Gulinck, H. (2003), "Satellite based land use and landscape complexity indices as predictors for regional plant species diversity", Landscape and Urban Planning, 63(4): 241-250, [DOI]. (Cited on pages 8, 9, 11, and 16.)

Howell, C.A., Latta, S.C., Donovan, T.M., Porneluzi, P.A., Parks, G.R. and Faaborg, J. (2000), "Landscape effects mediate breeding bird abundance in midwestern forests", Landscape Ecology, 15(6): 547-562, [DOI]. (Cited on page 19.)

Jackson, V.L., Laack, L.L. and Zimmerman, E.G. (2005), "Landscape metrics associated with habitat use by ocelots in south Texas", Journal of Wildlife Management, 69(2): 733-738, [DOI]. (Cited on page 9.)

Jaeger, J.A.G. (2000), "Landscape division, splitting index, and effective mesh size: new measures of landscape fragmentation", Landscape Ecology, 15(2): 115-130, [DOI]. (Cited on pages 9 and 16.)

Jaeger, J.A.G. (2002), Landschaftszerschneidung: Eine transdisziplinäre Studie gemäß dem Konzept der Umweltgefährdung, Stuttgart (Ulmer). (Cited on page 9.) 
Jedicke, E. (2001), "Biodiversität, Geodiversität, Ökodiversität: Kriterien zur Analyse der Landschaftsstruktur - ein konzeptioneller Diskussionsbeitrag", Naturschutz und Landschaftsplanung, 33(2/3): 59-68. (Cited on page 6.)

Jenness, J.S. (2004), "Calculating landscape surface area from digital elevation models", Wildlife Society Bulletin, 32(3): 829-839, [DOI]. (Cited on page 7.)

Jones, K.B., Neale, A.C., Nash, M.S., Van Remortel, R.D., Wickham, J.D., Riitters, K.H. and O'Neill, R.V. (2001), "Predicting nutrient and sediment loadings to streams from landscape metrics: A multiple watershed study from the United States Mid-Atlantic Region", Landscape Ecology, 16(4): 301-312, [DOI]. (Cited on page 11.)

Juutinen, A., Mönkkönen, M. and Ollikainen, M. (2008), "Do environmental diversity approaches lead to improved site selection? A comparison with the multi-species approach", Forest Ecology and Management, 255(11): 3750-3757, [DOI]. (Cited on page 19.)

Kaule, G. and Henle, K. (1991), "Überblick über Wissensstand und Forschungsdefizite", in Henle, K. and Kaule, G., eds., Arten- und Biotopschutzforschung für Deutschland, Berichte aus der Ökologischen Forschung, 4, pp. 2-44, Jülich (Forschungszentrum Jülich). (Cited on page 19.)

Kiel, S. and Albrecht, K. (2004), "Großräumige Landschaftsbewertung mit landscape metrics im Praxistest - Ein Methodenvergleich", in Strobl, J., Blaschke, T. and Griesebner, G., eds., Angewandte Geoinformatik 2004, Beiträge zum 16. AGIT-Symposium, Salzburg, 7. - 9. Juli 2004, pp. 323-332, Heidelberg (Wichmann). (Cited on pages 16 and 20.)

Knickel, K., Janßen, B., Schramek, J. and Käppel, K. (2001), "Naturschutz und Landwirtschaft: Kriterienkatalog zur 'Guten fachlichen Praxis"', Schriftenreihe für Angewandte Landschaftsökologie, 41, Bonn (Bundesamt für Naturschutz). (Cited on page 19.)

Kolasa, J. and Rollo, C.D. (1991), "Introduction: The heterogeheity of heterogeneity: A glossary", in Kolasa, J., Pickett, S.T.A. and Allen, T.F.H., eds., Ecological Heterogeneity, Ecological Studies, 86, pp. 1-23, New York (Springer). (Cited on page 7.)

Lamb, E.G., Bayne, E., Holloway, G., Schieck, J., Boutin, S., Herbers, J. and Haughland, D.L. (2009), "Indices for monitoring biodiversity change: Are some more effective than others", Ecological Indicators, 9(3): 432-444, [DOI]. (Cited on page 17.)

Lang, S. and Blaschke, T. (2007), Landschaftsanalyse mit GIS, Stuttgart (Ulmer UTB). (Cited on page 5.)

Lapin, M. and Barnes, B.V. (1995), "Using the landscape ecosystem approach to assess species and ecosystem diversity", Conservation Biology, 9(5): 1148-1158, [DOI]. (Cited on page 8.)

Lassen, D. (1979), "Unzerschnittene verkehrsarme Räume in der Bundesrepublik Deutschland", Natur und Landschaft, 54(12): 333-334. (Cited on pages 9 and 16.)

Lausch, A. and Herzog, F. (2002), "Applicability of landscape metrics for the monitoring of landscape change: issues of scale, resolution and interpretability", Ecological Indicators, 2(1-2): 3-15, [DOI]. (Cited on page 11.)

Lawler, J.J. and Edwards, T.C. (2002), "Landscape patterns as habitat predictors: building and testing models for cavity-nesting birds in the Uinta Mountains of Utah, USA", Landscape Ecology, 17: 233-245, [DOI]. (Cited on page 7.)

Li, H. and Reynolds, J.F. (1995), "On definition and quantification of heterogeneity", Oikos, 73 (2): 280-284, [DOI]. (Cited on page 7. )

Living Reviews in Landscape Research

http://www. livingreviews . org//rlr-2011-3 
Li, H. and Wu, J. (2004), "Use and misuse of landscape indices", Landscape Ecology, 19(4): 389399, [DOI]. (Cited on page 11.)

LIKI (2011), "Indikatoren", project homepage, Länderinitiative für einen länderübergreifenden Kernindikatorensatz (LIKI). URL (accessed 25 October 2011):

http://www.lanuv.nrw.de/liki-newsletter/. (Cited on pages 12 and 13.)

Lipp, T. (2009), "Berücksichtigung der biologischen Vielfalt in der raumbezogenen Umweltplanung", Naturschutz und Landschaftsplanung, 41(2): 36-40. (Cited on page 6.)

Mas, J.-F., Gao, Y. and Pacheco, J.A.N. (2010), "Sensitivity of landscape pattern metrics to classification approaches", Forest Ecology and Management, 259(7): 1215-1224, [DOI]. (Cited on page 7.)

McAlpine, C.A. and Eyre, T.J. (2002), "Testing landscape metrics as indicators of habitat loss and fragmentation in continuous eucalypt forests (Queensland, Australia)", Landscape Ecology, 17(8): 711-728, [DOI]. (Cited on page 11.)

McGarigal, K. and Cushman, S.A (2005), "The gradient concept of landscape structure", in Wiens, J.A. and Moss, M.R., eds., Issues and Perspectives in Landscape Ecology, Cambridge Studies in Landscape Ecology, pp. 112-119, Cambridge; New York (Cambridge University Press). Google Books. (Cited on pages 7 and 22.)

McGarigal, K. and Marks, B.J. (1995), "FRAGSTATS: Spatial Pattern Analysis Program for Quantifying Landscape Structure", General Technical Report, PNW-GTR-351, Portland, OR (USDA Forest Service, Pacific Northwest Research Station). Online version (accessed 12 October 2011):

http://www.fs.fed.us/pnw/publications/gtrs-prior-1997.shtml. (Cited on page 7.)

McGarigal, K., Cushman, S.A., Neel, M.C. and Ene, E. (2002), "FRAGSTATS: Spatial Pattern Analysis Program for Categorical Maps", project homepage, University of Massachusetts, Amherst. URL (accessed 12 October 2011):

http://www . umass. edu/landeco/research/fragstats/fragstats.html. (Cited on page 5.)

Miller, J.N., Brooks, R.P. and Croonquist, M.J. (1997), "Effects of landscape patterns on biotic communities", Landscape Ecology, 12(3): 137-153, [DOI]. (Cited on page 8.)

Moser, B., Jaeger, J.A.G., Tappeiner, U., Tasser, E. and Eiselt, B. (2007), "Modification of the effective mesh size for measuring landscape fragmentation to solve the boundary problem", Landscape Ecology, 22(3): 447-459, [DOI]. (Cited on page 15.)

Moser, D., Zechmeister, H.G., Plutzar, C., Sauberer, N., Wrbka, T. and Grabherr, G. (2002), "Landscape patch shape complexity as an effective measure for plant species richness in rural landscape", Landscape Ecology, 17(7): 657-669, [DOI]. (Cited on pages 8 and 16.)

Müller, D., Göbel, N., Karl, H. and Thamm, R. (2008), "Ermittlung der regionalen Mindestdichten von zur Vernetzung erforderlichen linearen und punktförmigen Elementen nach $\S 5$ (3) BNatschG", Natur und Landschaft, 83(8): 356-364. (Cited on pages 19 and 21.)

Müller, F. and Wiggering, H. (2004), "Umweltindikatoren als Maßstäbe zur Bewertung von Umweltzuständen und -entwicklungen", in Wiggering, H. and Müller, F., eds., Umweltziele und Indikatoren: Wissenschaftliche Anforderungen an ihre Festlegung und Fallbeispiele, Geowissenschaften + Umwelt, pp. 121-128, Berlin (Springer). (Cited on page 17.) 
Nagendra, H. (2002), "Opposite trends in response for the Shannon and Simpson indices of landscape diversity", Applied Geography, 22(2): 175-186, [DOI]. (Cited on page 12.)

Neel, M.C., McGarigal, K. and Cushman, S.A. (2004), "Behavior of class-level landscape metrics across gradients of class aggregation and area", Landscape Ecology, 19(4): 435-455, [DOI]. (Cited on page 11.)

Nichols, W.F., Killingbeck, K.T. and August, P.V. (1998), "The Influence of Geomorphological Heterogeneity on Biodiversity. II. A Landscape Perspective", Conservation Biology, 12(2): 371379, [DOI]. (Cited on pages 8 and 19.)

Noss, R.F. (1983), "A Regional Landscape Approach to Maintain Diversity", BioScience, 33(11): 700-706, [DOI]. (Cited on pages 10 and 20.)

Noss, R.F. (1990), "Indicators for Monitoring Biodiversity: A Hierarchical Approach", Conservation Biology, 4(4): 355-364, [DOI]. (Cited on page 6.)

Öckinger, E. and Smith, H.G. (2008), "Do corridors promote dispersal in grassland butterflies and other insects", Landscape Ecology, 23(1): 27-40, [DOI]. (Cited on page 20.)

O’Neill, R.V., Krummel, J.R., Gardner, R.H., Sugihara, G., Jackson, B., DeAngelis, D.L., Milne, B.T., Turner, M.G., Zygmunt, B., Christensen, S.W., Dale, V.H. and Graham, R.L. (1988), "Indices of landscape pattern", Landscape Ecology, 1(3): 153-162, [DOI]. (Cited on page 8.)

Ortega, M., Elena-Rosello, R. and García del Barrio, J.M. (2004), "Estimation of Plant Diversity at Landscape Level: A Methodological Approach Applied to Three Spanish Rural Areas", Environmental Monitoring and Assessment, 95(1): 97-116, [DOI]. (Cited on page 11.)

Plachter, H. (1991), Naturschutz, Stuttgart (Gustav Fischer UTB). (Cited on page 18.)

Rempel, R. (2008), "Patch Analyst for ArcGIS: Version 4", project homepage, Centre for Northern Forest Ecosystem Research. URL (accessed 12 October 2011): http://flash.lakeheadu.ca/ rrempel/patch/. (Cited on page 7.)

Rey Benayas, J.M. and de la Montaña, E. (2003), "Identifying areas of high-value vertebrate diversity for strengthening conservation", Biological Conservation, 114: 357-370, [DOI]. (Cited on page 19.)

Ricketts, T.H. (2001), "The Matrix Matters: Effective Isolation in Fragmented Landscapes", American Naturalist, 158(1): 87-99, [DOI]. (Cited on page 20.)

Ricotta, C., Corona, P., Marchetti, M., Chirici, G. and Innamorati, S. (2003), "LaDy: software for assessing local landscape diversity profiles of raster land cover maps using geographic windows", Environmental Modelling \& Software, 18(4): 373-378, [DOI]. (Cited on pages 8 and 11.)

Riitters, K.H., O’Neill, R.V., Hunsaker, C.T., Wickham, J.D., Yankee, D.H., Timmins, S.P., Jones, K.B. and Jackson, B.L. (1995), "A factor analysis of landscape pattern and structure metrics", Landscape Ecology, 10(1): 23-39, [DOI]. (Cited on page 11.)

Romero, S. (2007), Influence of Landscape Structure on Movement Behavior and Habitat Use by Red Flour Beetle (Tribolium Castaneum), Ph.D. Thesis, Kansas State University, Manhattan, KS. Online version (accessed 12 October 2011):

http://krex.k-state.edu/dspace/bitstream/2097/417/1/SusanRomero2007.pdf. (Cited on page 9.)

Living Reviews in Landscape Research

http://www. livingreviews.org/lrlr-2011-3 
Sala, O.E., Chapin III, F.S., Armesto, J.J., Berlow, E., Bloomfield, J., Dirzo, R., Huber-Sanwald, E., Huenneke, L.F., Jackson, R.B., Kinzig, A., Leemans, R., Lodge, D.M., Mooney, H.A., Oesterheld, M., Poff, N.L., Sykes, M.T., Walker, B.H., Walker, M. and Wall, D.H. (2000), "Global Biodiversity Scenarios for the Year 2100", Science, 287(5459): 1770-1774, [DOI]. (Cited on pages 17 and 21.)

Schindler, S., Poirazidis, K. and Wrbka, T. (2008), "Towards a core set of landscape metrics for biodiversity assessments: A case study from Dadia National Park, Greece", Ecological Indicators, 8(5): 502-514, [DOI]. (Cited on pages 7 and 11.)

Schmitt, E. [Leibniz-Institut für Länderkunde] (2004), "Natur- und Landschaftsschutzgebiete", in Nationalatlas Bundesrepublik Deutschland: Unser Land in Karten, Texten und Bildern, pp. 94-95, München; Heidelberg (Elsevier / Spektrum Akademischer Verlag). (Cited on page 19.)

Schüpbach, B., Gfeller, M., Jeanneret, P., Lips, A. and Bigler, F. (1999), "Wirkungskontrolle der landwirtschaftlichen Ökomaßnahmen für die Biodiversität im schweizerischen Agrarraum", in Blaschke, T., ed., Umweltmonitoring und Umweltmodellierung: GIS und Fernerkundung als Werkzeuge einer nachhaltigen Entwicklung, pp. 209-214, Heidelberg (Wichmann). (Cited on page 12.)

Shaffer, M.L. (1981), "Minimum population sizes for species conservation", BioScience, 31: 131134, [DOI]. (Cited on page 8.)

SRU - Sachverständigenrat für Umweltfragen (2005), "Umwelt und Straßenverkehr: Hohe Mobilität - Umweltverträglicher Verkehr. Sondergutachten", Baden-Baden (Nomos). (Cited on page 9.)

Stachow, U. (1995), "Naturraum- und Biotopausstattung", in Bork, H.-R., Dalchow, C., Kächele, H., Piorr, H.-P. and Wenkel, K.-O., eds., Agrarlandschaftswandel in Nordost-Deutschland unter veränderten Rahmenbedingungen: ökologische und ökonomische Konsequenzen, pp. 286-321, Berlin (Ernst und Sohn). (Cited on pages 12 and 16.)

Steiner, N. and Köhler, W. (2002), "Modellierung der Artendiversität auf verschiedenen Skalenebenen in Abhängigkeit von der Landschaftsstruktur", in Korn, H. and Feit, U., eds., Treffpunkt biologische Vielfalt II, pp. 205-208, Bonn (Landwirtschaftsverlag / BfN). (Cited on page 10.)

Steinhardt, U., Herzog, F., Lausch, A., Müller, E. and Lehmann, S. (1999), "The Hemeroby Index for Landscape Monitoring and Evaluation", in Pykh, Y.A., Hyatt, D.E. and Lenz, R.J.M., eds., Environmental Indices: Systems Analysis Approach, Proceedings of the First International Conference on Environmental Indices Systems Analysis Approach (INDEX-97) St. Petersburg, Russia, July 7-11, 1997, pp. 237-257, Oxford (EOLSS). (Cited on page 15.)

Strand, H., Höft, R., Strittholt, J., Miles, L., Horning, N., Fosnight, E. and Turner, W., eds. (2007), Sourcebook on Remote Sensing and Biodiversity Indicators: Prepared by the NASA-NGO Biodiversity Working Group and UNEP-WCMC to support implementation of the Convention on Biological Diversity, CBD Technical Series, 32, Montreal (Secretariat of the Convention on Biological Diversity). URL (accessed 25 October 2011): http://www.cbd.int/ts/. (Cited on pages 9, 12, and 16.)

Sukopp, U. (2007), "Der Nachhaltigkeitsindikator für die Artenvielfalt: Ein Indikator für den Zustand von Natur und Landschaft", in Gedeon, K., Mitschke, A. and Sudfeldt, C., eds., Brutvögel in Deutschland, pp. 34-35, Hohenstein-Ernstthal (Verein Sächsischer Ornithologen). (Cited on page 13.) 
Sundell-Turner, N.M. and Rodewald, A.D. (2008), "A comparison of landscape metrics for conservation planning", Landscape and Urban Planning, 86(3-4): 219-225, [DOI]. (Cited on pages 10, 16, and 21.)

Swenson, J.J. and Franklin, J. (2000), "The effects of future urban development on habitat fragmentation in the Santa Monica Mountains", Landscape Ecology, 15(8): 713-730, [DOI]. (Cited on pages 9 and 19.)

Tasser, E., Sternbach, E. and Tappeiner, U. (2008), "Biodiversity indicators for sustainability monitoring at municipality level: An example of implementation in an alpine region", Ecological Indicators, 8(3): 204-223, [DOI]. (Cited on pages 15, 16, and 17.)

Tews, J., Brose, U., Grimm, V., Tielbörger, K., Wichmann, M.C., Schwager, M. and Jeltsch, F. (2004), "Animal species diversity driven by habitat heterogeneity/diversity: the importance of keystone structures", Journal of Biogeography, 31(1): 79-92, [DOI]. (Cited on page 13.)

Tiede, D., "V-LATE: Vector-based Landscape Analysis Tools Extension", project homepage, University of Salzburg. URL (accessed 22 September 2011):

http://www.geo.sbg.ac.at/larg/vlate.htm. (Cited on page 7.)

Tischendorf, L. (2001), "Can landscape indices predict ecological processes consistently?", Landscape Ecology, 16(3): 235-254, [DOI]. (Cited on page 11.)

Turner, M.G. (1989), "Landscape Ecology: The Effect of Pattern on Process", Annual Review of Ecology and Systematics, 20: 171-197, [DOI]. (Cited on pages 8 and 17.)

Turner, M.G. (2005), "Landscape ecology: What is the state of the science?", Annual Review of Ecology, Evolution, and Systematics, 36: 319-344, [DOI]. (Cited on pages 10 and 22.)

Turner, M.G., Gardner, R.H. and O'Neill, R.V. (2003), Landscape Ecology in Theory and Practice: Pattern and Process, New York; Berlin (Springer), 2nd edn. (Cited on page 5.)

Umweltbundesamt (2007), "Environmental data for Germany: Environmental indicators", DessauRoßlau (German Federal Environment Agency). Online version (accessed 12 October 2011): http://www. umweltdaten.de/publikationen/fpdf-1/3436.pdf. (Cited on page 12.)

UNEP (2001), "Indicators and environmental impact assessment: Designing national level monitoring programmes and indicators", UNEP/CBD/SBSTTA/7/12, Montreal (UNEP/CBD). Online version (accessed 25 October 2011):

http://www.cbd.int/doc/meetings/sbstta/sbstta-07/official/sbstta-07-12-en.pdf. (Cited on page 15.)

United Nations (1993), "Multilateral Convention on Biological Diversity (with annexes): Concluded at Rio de Janeiro on 5 June 1992", Treaty Series, 1760: 142-382, I-30619, New York (United Nations). Online version (accessed 25 October 2011):

http://treaties.un.org/doc/Publication/UNTS/Volume1760/v1760.pdf. (Cited on page 5.)

Uuemaa, E., Antrop, M., Roosaare, J., Marja, R. and Mander, Ü. (2009), "Landscape Metrics and Indices: An Overview of Their Use in Landscape Research", Living Reviews in Landscape Research, 3(1), lrlr-2009-1. URL (accessed 1 March 2011): http://www.livingreviews.org/lrlr-2009-1. (Cited on pages 5 and 8.) 
Visser, U. and Wiegand, K. (2004), "Einfluss der Struktur von Agrarlandschaften auf die Biodiversität", in Agrarproduktion und Biodiversität, Tagungsband zum Kolloquium in Jena, 18. Mai 2004, pp. 58-62, Erfurt (TMLFUN). Online version (accessed 24 October 2011): http://www.thueringen.de/de/publikationen/pic/pubdownload568.pdf. (Cited on pages 9 and 11.)

Wagner, H.H. and Edwards, P.J. (2001), "Quantifying habitat specificity to assess the contribution of a patch to species richness at a landscape area", Landscape Ecology, 16(2): 121-131, [DOI]. (Cited on page 22.)

Waldhardt, R. and Otte, A. (2000), "Zur Terminologie und wissenschaftlichen Anwendung des Begriffs Biodiversität", Wasser \&3 Boden, 52(1/2): 10-13. (Cited on page 6.)

Walz, U. (2006), "Landschaftsstruktur - zwischen Theorie und Praxis", in Kleinschmit, B. and Walz, U., eds., Landschaftsstrukturmaße in der Umweltplanung, Beiträge zum Workshop der IALE-AG Landschaftsstruktur, Berlin 2006, Landschaftsentwicklung und Umweltforschung, S19, pp. 4-17. Google Books, Berlin (TU Berlin). (Cited on page 5.)

Walz, U. and Schauer, P. (2009), "Unzerschnittene Freiräume als Schutzgut?: Landschaftszerschneidung in Deutschland mit besonderem Fokus auf Sachsen", in Siedentop, S. and Egermann, M., eds., Freiraumschutz und Freiraumentwicklung durch Raumordnungsplanung: Bilanz, aktuelle Herausforderungen und methodisch-instrumentelle Perspektiven, ARL-Arbeitsmaterial, 349, pp. 46-70, Hannover (ARL). (Cited on page 9.)

Weinzierl, H. (2004), "Biodiversität - eine politisch-gesellschaftliche Herausforderung", Berichte $\operatorname{der} A N L, 28: 17-23$. (Cited on page 22.)

Wiens, J.A. (1989), "Spatial scaling in ecology", Functional Ecology, 3(4): 385-397, [DOI]. (Cited on page 7 .)

Wiersma, Y.F., Nudds, T.D. and Rivard, D.H. (2004), "Models to distinguish effects of landscape patterns and human population pressures associated with species loss in Canadian national parks", Landscape Ecology, 19(7): 773-786, [DOI]. (Cited on page 19.)

With, K.A. (2005), "Landscape conservation: a new paradigm for the conservation of biodiversity", in Wiens, J.A. and Moss, M.R., eds., Issues and perspectives in landscape ecology, Cambridge Studies in Landscape Ecology, pp. 238-247, Cambridge (Cambridge University Press). (Cited on page 19.)

Wrbka, T. et al. [Projektteam SINUS] (2003), "Endbericht zum Forschungsprojekt SINUS: Landschaftsökologische Strukturmerkmale als Indikatoren der Nachhaltigkeit (Spatial INdicators for Land USe Sustainability)", Wien (BMBWK). (Cited on pages 5 and 15.)

Xiang, W.-N. (1996), "GIS-based riparian buffer analysis: injecting geographic information into landscape planning", Landscape and Urban Planning, 34(1): 1-10, [DOI]. (Cited on page 15.)

Zebisch, M. (2002), "Vom Landschaftsmuster zur ökologischen Bewertung: Bericht von zwei Konferenzen der IALE in Amerika und Europa", Landschaftsplanung.NET, 2002. URL (accessed 12 October 2011):

http://www.lapla-net.de/texte/2002/zebisch/zebisch.pdf. (Cited on page 22.)

Zebisch, M. (2004), Modellierung der Auswirkungen von Landnutzungsänderungen auf Landschaftsmuster und Biodiversität, Ph.D. Thesis, TU Berlin, Berlin. Online version (accessed 12 October 2011):

http://opus.kobv.de/tuberlin/volltexte/2004/814/. (Cited on pages 10 and 11.) 